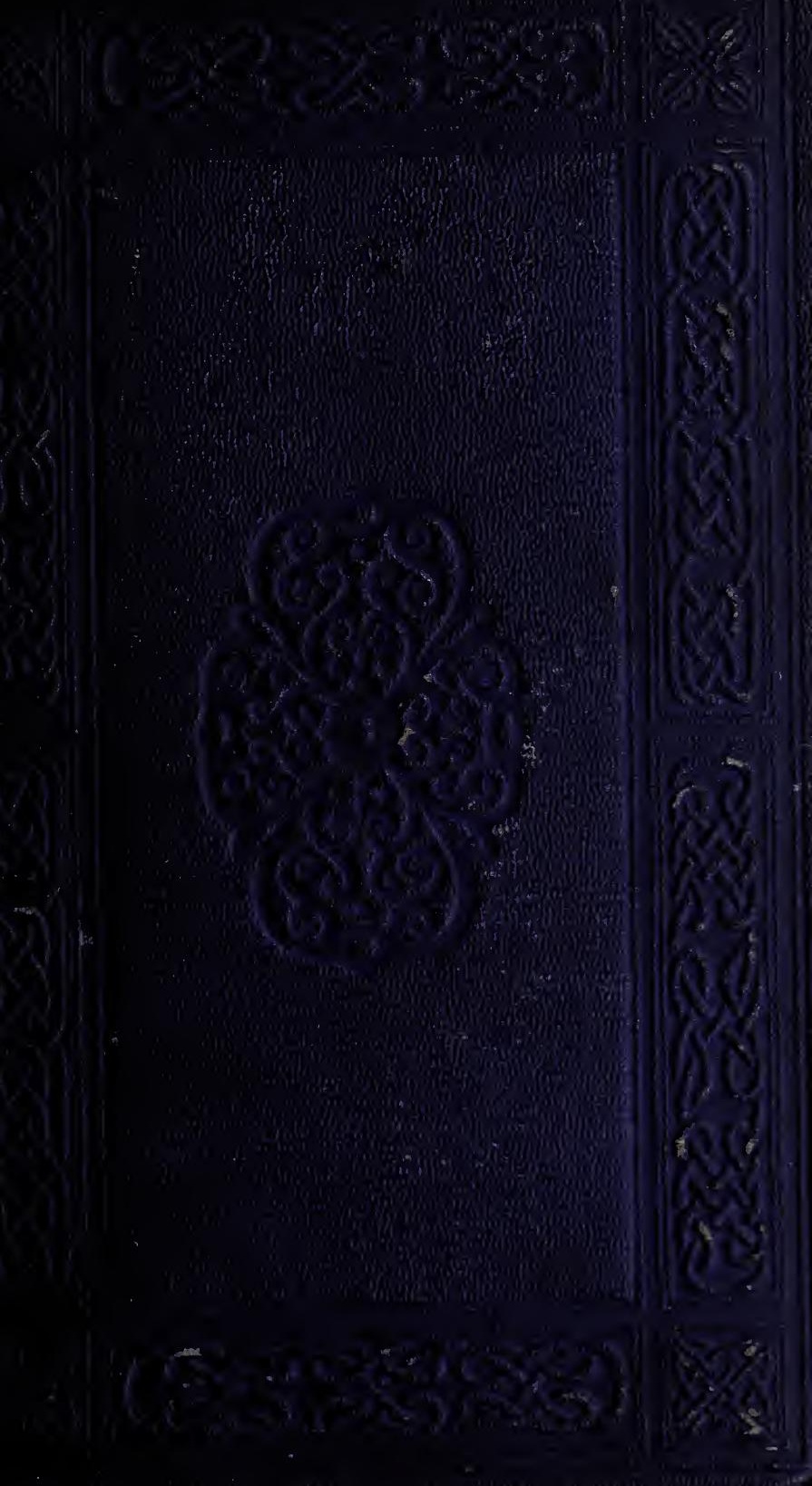




\section{Library}

$$
\text { of the }
$$

University of Toronto 


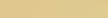

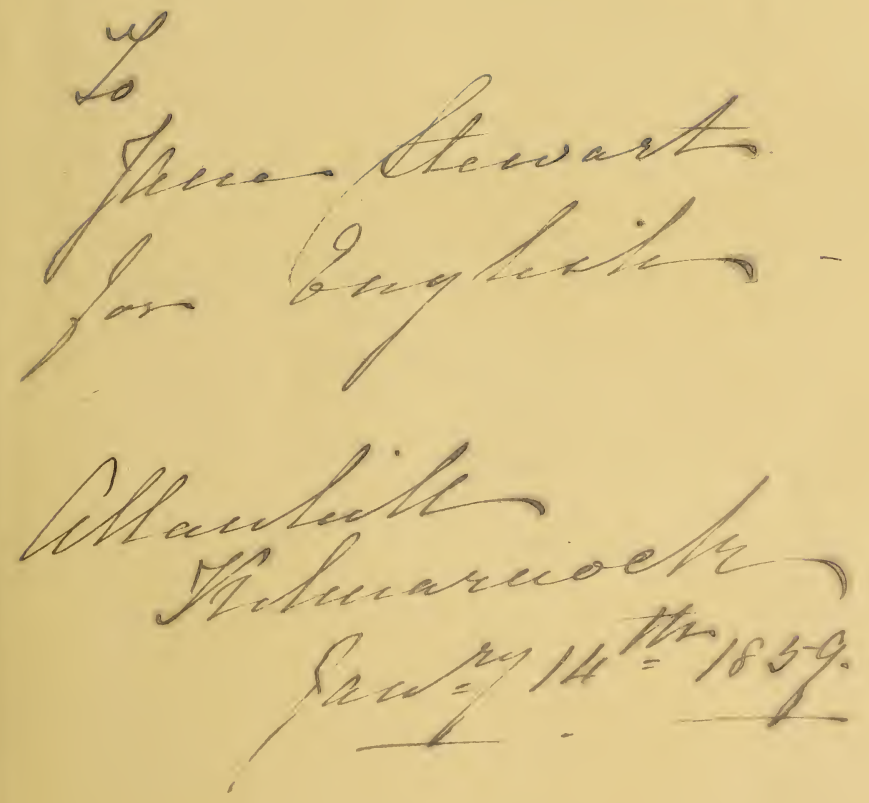





\section{SEA-SIDE PLEASURES.}




\section{LON DON :}

PHINTED BY C. ROWORTH AND SONS,

BELL YARD, TEMPLE BAR. 


\section{SEA-SIDE PLEASURES:}

OR

\section{A PEEP AT MISS ELDON'S HAPPY PUPILS.}

\section{BY}

\section{ELIZABETH ANNE ALLOM,}

DAUGHTER OF THE LATE REV. S. R. ALLOM,

AN D

Author of "The Sea-Weed Collector," "Death Scenes, and other Poems."

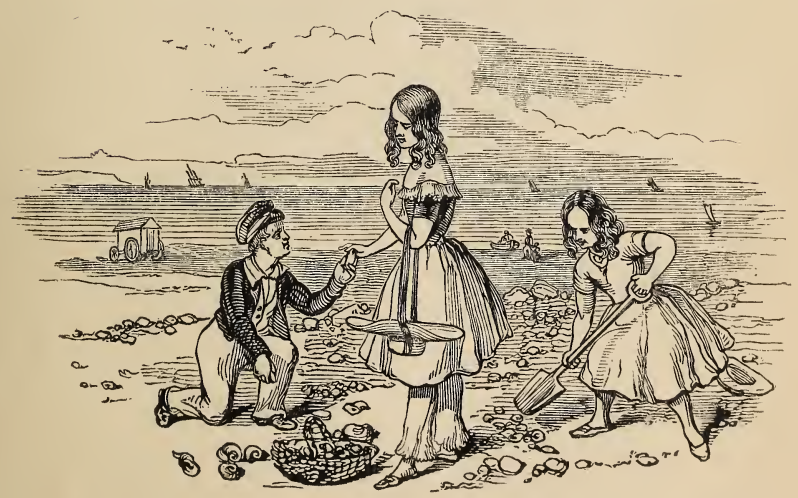

L O N DON :

AYLOT'T AND JONES, 8, PATERNOSTER ROW. 



\section{THIS LITTLE WORK}

is

AFFECTIONATELY INSCRIBED

TO

THOSE WHO WILL RECOGNIZE IN THE AUTHOR'S NAME THAT OF AN OLD FRIEND

OR SOMETIME GOVERNESS. 



\section{PREF A CE.}

My dear Young Friends,

To some of you, I doubt not, many incidents in the following pages will be perfectly familiar; for, although names, places, \&c. are altered, most of the circumstances therein recorded, and many of the pleasant walks there described, have been enjoyed or witnessed in your society, or mentioned to you after their occurrence to myself. This will, I hope, rather increase the interest to you, as it has done to myself, by recalling the pleasant days that are past.

Many of you will remember the delight with which we then discovered a new wild flower, shell, or sea-weed, and tried to find out its properties or peculiarities. With a few, perhaps, 
this interest has altogether ceased; while, with others, it retains all its freshness and purity.

Be this as it may: it is probable that my little book may be read by some to whom these subjects are altogether new, and I am anxious that, while the little information I here profess to give may interest them sufficiently to make them resolve by all means to acquire more, they should not imagine that enough is taught here to give even a tolerable degree of knowledge on these subjects. Far from it. The object with which I have especially written, is to induce desire for further instruction-to point the young mind, which naturally seeks and requires frequent relaxation, to amusements worthy of its capabilities and high requirements. I have led it to the threshold of the beautiful temple of Natural Science, and trust that the glimpse here afforded may make it truly desirous to gain a standing within its sacred precincts-sacred, because all its trea- 
sures are the immediate work of Him, who by his breath caused man to becorne a living soul, capable of appreciating the wonders of His creating love, and of rejoicing in the works of His hands.

I must not close without acknowledging the obligations I am under to the talented authors of Lessons on Shells, Algæ Britannicæ, \&c. \&c. for much interesting anecdote and valuable information; and having done this, I beg to subscribe myself,

$$
\begin{aligned}
& \text { My dear young Friends, } \\
& \text { Your's, very sincerely, }
\end{aligned}
$$

E. A. A.

3, St. Paul's Place, Islington,

July 3, 1845. 



\section{CONTENTS.}

Chap. I.

Introduction

$\begin{array}{cccccc}\text { C } & \ldots & \ldots & \ldots & \text {. } & \text { Page I } \\ \text { Chap. II. }\end{array}$

The Voyage-Ships in the River-Nore Light-Arrival at Ramsgate-First Day at the Sea Side-Walk on the Sands-Proposed Pleasures-Sea-Weeds, Fossils, Shells, \&c.

\section{Chap. III.}

Beauties of Creation-Ellen's first Sea-Weeds-Scotch Dulse-Willie's Shells-Snail Nurseries-Mollusks,

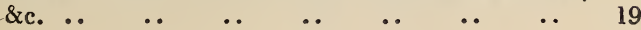

\section{Chap. IV.}

Three Divisions of Shells-Origin of the Words Univalve, Bivalve and Multivalve-Walk on the Sands-Temper -The Chiton-Visit to the Fisherman's CottagePholas-Lepas

$$
\begin{array}{ll}
\cdots & \cdots \\
\text { Chap. V. }
\end{array}
$$

Excursion for Fossils-Sketch of Geology-A StrangerHelix - Echinus-A Narrow Escape .. ..

$$
\text { Chap. VI. }
$$

The Class Bivalve 
Chap. VIII.

Walk to the West Sands-The Lepas, or Barnacle-The Cement House - The Wreck - A Visitor-Leslie's Story-An Accident - Dover Castle-The Debtors' Gaol-Fossils-Pleasant Tidings .. $\quad$. $\quad$..

Chap. IX.

The Disappointment-Industry the Best Cure .. _ . 99

Chap. X.

The Reconciliation-Remarks on the Algæ-The Class Univalve

Chap. XI.

In-doors Amusements - The Visit to Shell Nest-The

Coast-guard's Home-The Fall-The Sudden Return 123

Chap. XII.

Conclusion 


\section{SEA-SIDE PLEASURES.}

\section{$\rightarrow$ \\ Chapter I.}

I N T RO DU C T ION.

"ANd does Dr. Percy think that dear mama is really getting better?" said Leslie Carlton to his sister Ellen, who had just left her mother's dressing-room. "Yes, indeed, Leslie, Dr. Percy hopes that she will soon be quite strong and well; and I have more good news for you still, so come into the school-room and you shall hear all about it, for it is a pleasure which concerns us all."

"A pleasure which concerns us all !" repeated little Mary, whose quick ear had caught her sister's words as she opened the schoolroom door. " Oh tell us, do tell us !" And she jumped from her seat, and put her arms coax- 
ingly round Ellen's neck. But Ellen was at this moment inclined for a little mischief, so she put on a very grave look and declared that she would not tell them any thing about it until they had guessed all round.

"I know! I think I know," said Willie. "Papa will take us to the Adelaide Gallery at last."

"Wrong, quite wrong! Now, Mary, what do you guess?" “Perhaps aunt Alice has brought me my wax doll," said the child, her eyes sparkling with pleasure.

“Why you little goose!" exclaimed Leslie quickly, "how could that be a pleasure to concern us all; Willie and I could not nurse your doll, could we?" The little girl seemed hurt at her brother's rough manner, but she quickly recovered her good humour, and begged Leslie to try if he could do better.

He puzzled for some time, and at last said, "That as mama was better, perhaps they were to have a little party to keep Ellen's birthday which had occurred the week before."

"No, indeed," said Ellen, " the pleasure we 
are to have is better than all three put together."

"What better than the Adelaide Gallery and the diving-bell!" "Better than a doll with wax legs and arms !" exclaimed Willie and Mary in a breath, "Oh, Ellen, do, do tell us !"

"Yes, really, Ellen, you have quite excited our curiosity," said Miss Eldon, their kind governess, who had been patiently listening to their conversation. "What can this great pleasure possibly be?"

"Well then, you shall hear," said Ellen. " Dr. Percy thinks dear mama much better, and says, that a few weeks at the sea-side will be more likely to establish her health than any thing else; and I heard papa promise that he would make every arrangement, and start, if possible, at the end of next week; and more than that, papa said that the sea-breezes would do us all good, and he and dear mama talked about it a little while, and settled that we were really to go, and then they gave me permission to come and tell you."

The delight of the children at this pleasant 
intelligence may be easily imagined; they clapped their hands and jumped about for very joy! and when Mr. Carlton himself came in and confirmed all that Ellen had told them, there seemed to be no bounds to their happiness.

Perhaps, before we proceed any farther with our story, our young readers would like to know something more of the little girls and boys they have found thus pleasantly interrupted in their morning studies: we shall be very happy to gratify them.

Mrs. Carlton's family consisted of the two boys and two girls we have already mentioned, and a little interesting baby who had not yet left the nursery. Ellen, the eldest of the five, was a tall thoughtful girl of fourteen, kind, amiable and affectionate, ever ready to give pleasure to those around her, and willing, at any moment, to relinquish her own gratification if she could add to that of her brothers and sisters.

Leslie, who had just attained his twelfth year, was, we are sorry to say, not quite so 
mild and amiable; he was somewhat headstrong and self-willed, but of a generous disposition, and always ready to acknowledge and repair an error.

After the Midsummer vacation, Leslie, whose studies had been hitherto superintended by Miss Eldon, was to enter a public school, and as is frequently the case with boys of his age, he began to think himself already superior to the society of his sisters and their truly excellent governess; we might have guessed something of the sort from his rather rude speech to poor little Mary about the doll.

Willie was not quite ten years old, and, like his sister Ellen, he was steady and thoughtful beyond his years; and having always been a delicate child, and unable to partake the rough and boisterous sports in which his brother delighted, had acquired a great taste for reading and quiet study; he was very fond of history and the many valuable little books written for the entertainment and instruction of the young.

Mary was a merry romp, not six years old, full of life and spirits, and finding it the 
most difficult thing in the world to sit still for five whole minutes together.

As for Lucy, little baby Lucy, she was the happy, laughing, blue-eyed pet of the whole circle; even Leslie became gentle and careful when he took the curly-headed darling from her nurse's arms and cantered round the schoolroom with her on his back. But baby Lucy was not often allowed to visit the school-room, for she was found a sad hindrance to steady lessons of Latin and French.

Until about six months before the time at which our story commences, these dear little ones had not known any thing of trouble or sorrow; but their kind mama, whom they all most tenderly loved, was then suddenly seized with a severe and dangerous illness, and for many long and tedious weeks Dr. Percy gave no hope that her valuable life could be preserved. Many tears did these dear children shed together, and many anxious hours did they pass in sorrowful suspense; and when at length they were permitted to steal softly one by one into the darkened chamber, they could 
scarcely believe that the poor, faded, and wasted form before them was indeed that of their own beloved mama. But Mrs. Carlton gradually recovered, and for the last fortnight the children had been allowed to spend an hour or two with her every day; and now that Dr. Percy had given it as his opinion that a few months at the sea-side would confirm her returning health and strength, we cannot wonder that they were indeed thankful and happy, and that this hope, added to the anticipated pleasure of a visit to Ramsgate, should have made the week that preceded their departure seem a very very long one to their ardent wishes. But there were boxes to pack, and summer dresses to be thought about, and dolls and favourite books to be put carefully away, so the days glided by one after another, and still left some pleasant preparation to occupy to-morrow. Poor Miss Eldon, the only one of the party who had ever visited the Kentish coast, was constantly assailed with wonders and inquiries respecting all they were to see and enjoy, now that the long dreary winter 
8 SEA-SIDE PLEASURES.

had given place to merry spring, and the foggy air and formal pavements of London were to be exchanged for sea-breezes, and joyous rambles on the pier and sands. 


\section{$(9)$}

\section{Chapter II.}

THE VOYAGE-SHIPS IN THE RIVER-NORE LIGHT-ARRIVAL AT RAMSGATE-FIRST DAY AT THE SEA SIDE - WALK ON THE SANDS-PROPOSED PLEASURESSEA-WEEDS, FOSSILS, SHELLS, \&C.

The expected day came at length, and surely a May morning full of sunshine and beauty never greeted a happier or gayer circle.

Two coaches were at the door at a very early hour, and long before nine o'clock they were all safely on board the gaily painted steampacket, which was to convey them to Ramsgate.

The fresh sweet air seemed to invigorate and refresh the still feeble invalid. She had borne the fatigue of the ride better than they had hoped, and was just comfortably settled on a sofa in the saloon, when the warning bell ceased ringing and the vessel began to move. The paddle wheels turned swiftly round, the tall masts of the ships in the river rapidly disappeared, and our little friends were very glad to 
find that they were losing sight of London, and travelling smoothly and pleasantly on the quiet water.

Little Mary, who with Miss Eldon's arm tightly grasping her, was leaning over the side of the vessel, called eagerly to Willie to come and see the soap-suds; and while Willie explained to her that the white foam she saw was occasioned by the constant splashing of the paddles, Leslie seized his papa's arm and begged he would explain to him, how so large a vessel should really be made to move with the steam of boiling water.

Ellen was all this time quietly seated at her mama's side, and the dear child found more pleasure in thus contributing to her happiness and comfort, than she would have done in all the novelty and excitement of the deck. In this manner, Greenwich, Woolwich and Gravesend were speedily passed, and many a fine vessel and swift sailing packet excited the wonder and admiration of the young travellers.

Between twelve and one o'clock, they reached the Nore Light, and Willie was quite astonished 
to think that men could be found bold and hardy enough to live in so small a vessel in the middle of the water, and exposed to so much danger.

"Oh, my boy," said Mr. Carlton, who heard his remark, "you know very little at present of the dangers of the ocean, and of the bravery of those poor fellows who constantly expose their lives upon its wild billows; we owe much to seamen, Willie, for their dauntless courage; they are generally speaking noble fellows, and deserve the gratitude and kindness of their countrymen."

But we must not spare time to describe all the pleasure and instruction the passage afforded. Many of our little readers are doubtless already acquainted with its attractions, and we trust that all may one day enjoy the gratification for themselves. Merrily as the day passed, the children all joyfully hailed the first announcement that Ramsgate was in sight, and very glad were they, after the hurry and bustle of landing was over, to find themselves in their new and pleasant home, and to rest their poor weary heads on their welcome pillows. 
The fatigues of the previous day did not prevent Leslie from waking at an early hour the ensuing morning, and he was so full of curiosity and eagerness that he jumped quickly out of bed, and having roused his brother, the two boys hastily dressed and amused themselves in the drawing-room balcony, for a full hour before their papa and sisters came down to breakfast. The morning meal was quickly despatched, and Miss Eldon having promised to remain with Mrs. Carlton, the kind papa and his happy little ones sallied forth for their first ramble on the sea-shore.

We cannot mention all the curious and beautiful things they saw and talked about. Amusement and pleasure seemed to surround them on every side. Little Mary wanted a ride on one of the donkeys on which she found little boys and girls so happily mounted. Leslie thought it must be the most delightful thing in the world to be sailing in one of the pretty, pleasant-looking boats, with their snow white sails and gay coloured streamers, while Ellen and Willie busily employed themselves 
in searching for shells and pebbles, and other curiosities which they found plentifully scattered along the sea-shore. They returned home quite tired, but with much to tell and many important questions to ask. And as the sky clouded over in the afternoon, and frequent showers of rain made the ground damp and uncomfortable, they were obliged to content themselves at home for the remainder of the day.

When dinner was over, and the children had retired to their own sitting-room, Miss Eldon told them that she had a plan to propose which she thought would add much to their happiness and amusement during their stay at the sea-side, which Mr. Carlton had proposed should extend to two whole months. "And this, my dears," she added, "would be a long time, indeed, to spend in wandering from place to place, without acquiring useful knowledge of any kind. I think, my dear children, that none of you would feel quite happy in leading a life so useless and idle."

"But, Miss Eldon," interrupted Leslie, 
"you do not surely mean that we are all to sit down to our regular lessons, the same as we did in London; I should not like that at all."

"No indeed, Leslie, I have no such intention; and I think you will believe this when I tell you that I have promised your mama to relinquish my own holiday, which I usually spend with my friends in Leicester, in order that your pleasure may not be shortened, but that you may enjoy the whole of the visit here, and not have your studies interrupted again."

The children crowded round their kind friend, to kiss and thank her for this new proof of her affection; and Leslie, who felt ashamed of the warmth with which he had spoken, entreated Miss Eldon to tell them her plans, for he was quite sure they would all like to follow them.

"You shall do just as you please, my dear boy; my only wish is to add to your happiness and comfort; but you must judge for yourselves. I know that Ellen will be unwilling to neglect her music, and I think you proposed to read a littleLatin with your papa, but I foresaw 
that without settled and full employment, time would naturally drag heavily on your hands. I therefore persuaded your papa, before we left London, to make several little purchases, which I shall now joyfully put into the hands of those who are willing to make use of them. You, dear Ellen, have already a very nice collection of dried plants and flowers, and you have now a good opportunity of adding to them some of the beautiful sea-weeds with which this coast abounds. The algæ, or sea weeds, together with grasses, lichens and mosses, form, as I dare say you will recollect, the lowest order of botany, cryptogamia. I shall be happy to render you any assistance in collecting and arranging them; and although the names are often difficult, and the study requires care and attention, I have no doubt we shall get on very well."

Miss Eldon then gave Ellen a pretty little basket, lined with oil-silk, in which to collect her weeds, and a neat portfolio to arrange them in when dry.

"And what am I to do?" said Leslie, "I am 
so fond of natural history ; but indeed I ought to wait until last, for having been so impatient." " Well, Leslie, I will give you the present your papa has provided for you, and you shall try if you can guess its use;" and she put into his hand a large coarse bag of green baize, and an instrument in form and shape very much resembling a small pickaxe. Leslie was quite at a loss; he turned it round and round in his hand, but could not solve the mystery, so he was at length obliged to ask Miss Eldon to explain it to him. "You will remember," she said, "going last summer with your mama and papa to visit Mr. Knowles, and that your papa very much admired his valuable collection of fossils, many of which had been found on the Devon and Kentish coasts. You are a famous walker, and with your bag, and pickaxe in your hand, will enjoy accompanying your papa, who is similarly provided, and very anxious to begin his collection. And now for dear Willie, who is not able to work quite so hard." A little basket was provided for him, similar to Ellen's, 
and a square mahogany box, divided into small compartments, each neatly marked with printed tickets; this, Miss Eldon told him, was to contain his collection of shells. "Oh, thank you, dear, kind, good Miss Eldon," said Willie; "you knew that I was so fond of shells. Oh how happy we shall all be! and will you indeed teach me their names, and how to arrange them in my little box?"

Their kind friend promised to assist them all, and taking little Mary on her knee, told her, that, although she was not quite old enough to learn about these curious things herself, yet that she too should have a basket, and help Ellen and Willie to collect their weeds and shells. She also gave the little girl a small wooden spade with which to build herself a house or an island whenever she went on the sands.

"What grand people we shall be!" said Willie. "I know what a person who collects shells is called. I remember reading it in the Penny Magazine last week. I shall be a conchologist." 
18

SHELLS, ETC.

"Quite right, my boy; and Ellen will be an algologist, or collector of marine or sea plants ; and Leslie will be a geologist. But now it is tea time, and we must not keep mama waiting." 


\section{( 19$)$}

\section{Chapter III.}

BEAUTIES OF CREATION-ELLEN'S FIRST SEA-WEEDSSCOTCH DULSE-WILLIE'S SHELLS-SNAIL NURSERIES-MOLLUSKS, ETC.

Miss Eldon was herself a student of natural history, and the idea had occurred to her, that while a total relaxation from close study seemed necessary for the health of her pupils, yet that by combining information on these subjects with the amusements she wished them to enjoy, she should not only prevent their wearying of pleasure, but be enabled to lead their young hearts in wonder and admiration to dwell upon the glorious works of the Almighty Creator.

Perhaps the little girl or boy who is reading this history may be frequently in the habit of visiting the sea-side, or making excursions into the country, and while every weed and shell, every tree and flower has invited them to come and examine their beauty, and praise the wonderful hand that formed them, they have passed on with an unobservant eye and careless heart. 
Dear little reader, you will lose half the instruction and happiness the Almighty intended you to enjoy, if you pass heedlessly by the thousand beauties which are scattered around you on every hand.

Come now, and let us examine Ellen's first basket of sea-weed; did you ever imagine that the wide and boisterous ocean could contain objects so minute and beautiful? See her kind governess is helping her to examine them, and telling her some of their names and orders, Ellen has gathered some of every description today, because she was afraid of passing by any valuable specimens; in a little time she will be better able to judge, and will not bring home quite so much rubbish.

"See, Miss Eldon," said Ellen, "here are some large coarse weeds; I suppose I need only preserve parts of them just for specimens; they are not very pretty, but perhaps I had better not throw them away."

"No, Ellen, your collection will not be complete without them; and although you are not vet old enough to remember their long difficult 
names, I shall wish you to learn to distinguish the principal plants, and I hope you will some day be able to arrange and classify them all. You have one treasure here I see among your coarse leaves; this thick, tough plant, which looks so much like a piece of shoemakers' leather, is not often found at this season so perfect and rich in colour; it is called in Scotland "Best dulse," and is eaten by the Highlanders, and is even yet occasionally sold in the streets of Edinburgh, where, with the tangle, it was once a common commodity. This plant formed almost the only remaining article of food in the time of the dreadful famine in the Scottish Highlands some years since."

"Oh dear!" exclaimed Willie, "who would think that this dark looking sea-weed could have been so useful and interesting! but please, dear Ellen, make haste, for I am longing to show Miss Eldon some of my beautiful shells."

The fine small weeds were now examined, and Miss Eldon directed Ellen to place them in fresh spring water, promising that after dinner she would teach her to preserve them. 
Willie's turn came at length, and he found many treasures in his basket, which he was anxious to name and deposit in his box. He had been furnished by his mama with a little book containing some pretty coloured engravings, as well as descriptions of shells, one or two of which he was delighted to find in his collection; but they were much smaller and less beautiful than the drawings before him, and he could not conceal his disappointment.

Miss Eldon explained to him that the shells collected on the English coast are seldom so large and beautifully marked as the species which inhabit hot climates, although they are divided into the same classes and orders.

"Would you not be surprised, Willie," she said, " to find a snail in England, whose shell was large enough to contain ten quarts of liquid? It is related that such a monstrous snail-shell was once in existence, and although I cannot vouch for the truth of the story, yet we are quite certain that they attain to a very large size in many parts of the world; and in Rome, where in ancient days large nurseries were kept, 
on purpose for them, they are still eaten and esteemed a great delicacy. But, Willie, I should like your shells regularly arranged, and as the study is at first a little difficult, and will occasion you rather more trouble than you are aware of, I have another plan for you which I think you will like."

"Oh I am quite sure of it," said Willie, "I always like your plans, dear Miss Eldon."

"Well, you remember that when uncle William came to see you at Christmas, he was so kind as to give you a sovereign, which you placed in my care until we could think of some useful way for disposing of it. Now I know that that there is a little shop in this neighbourhood kept by a poor fisherman, where foreign shells may be purchased at a very moderate price; and if you like it, I will promise that whenever you conquer the difficulty of learning the description of a shell, with its generic name, we will purchase a pretty foreign one to place with yours, or to supply the place of any you have not been able to procure."

Willie was delighted, he clapped his hands 
for joy, and took a shell from his basket that he might begin his lesson at once.

"No, no, not so fast, Master Willie, if you please. We must learn something about the inhabitants of these pretty little dwellings, before we attempt to examine a separate shell, and we have many other things to talk about; so listen attentively, and I will explain to you."

"Linnæus, a celebrated naturalist, who lived a great many years ago, rendered the study of shells comparatively easy by dividing them into classes, each known by separate names, and the particular colouring and formation of their several members.

"It is according to his plan that I intend to teach you, because it is the most simple for beginners, but as there have been many improvements and discoveries since his time in the science of conchology, we shall occasionally make use of the assistance afforded us by other and more recent naturalists. Shells are the coverings or habitations for animals with cold soft bodies, without bones and slimy to the touch. Yet lifeless and uninteresting as these crea- 
tures appear, they all have nerves, glands, muscles, and a heart, in the vessels of which, instead of blood, a cold white fluid regularly circulates. Some of these curious animals have visible heads, others appear to have none; take an oyster and a snail for example; now, Willie, which of the two has a distinct head?"

"Oh, the snail, I am sure," cried little Mary; " the snail has a head and horns too."

"Quite right, little Mary," said Miss Eldon; " and try to remember, Willie, that those molusks which possess heads generally inhabit a shell consisting only of one piece or valve."

"Thank you, ma'am, I will try to remember, and now may I learn something about the dwelling-houses of these curious little fish?"

"Another time, my dear, but you must not call them fish: remember a snail cannot be called a fish; but the name by which they are known will apply to all the inhabitants of shells, found either in land or water. They are called Mollusca, rather a difficult name to remember, is it not? But here is pet Lucy come for a romp; we will have another lesson 
to-morrow, Willie, before breakfast, if you please."

The children put away their books, and, in less than ten minutes, the whole party were enjoying a delightful game at "Puss catch Corner." 


\section{$27 \quad)$}

\section{Chapter IV.}

THREE DIVISIONS OF SHELLS-ORIGIN OF THE WORDS UNIVALVE, BIVALVE AND MULTIVALVE-WALK ON THE SANDS-TEMPER-THE CHITON-VISIT TO THE FISHERMAN'S COTTAGE-PHOLAS - LEPAS.

Litrle Willie was tapping at Miss Eldon's door at a very early hour the next morning; he was delighted to find her already dressed, and waiting to fulfil her promise. They went together into the sitting-room, and Miss Eldon put three small shells into Willie's hand, desiring him to see if he could find any very striking difference between them.

"They are all of different shapes and colours," said Willie, "but then I know that many snail-shells are differently formed and marked, and yet we should call them all snailshells." So he thought again for a minute or two, and looked at them very attentively, till Miss Eldon could see by his sparkling eyes and animated countenance that he had found the secret at last. Oh! how many little boys 
and girls abandon a difficulty when they have scarcely given themselves a moment's thought or care about it! But kind Miss Eldon had taught Willie always to try and understand a thíng himself first, and never to give it up until he had thought carefully and seriously about it. So Willie looked very pleased and happy when he told Miss Eldon that " he thought the difference she meant was, that the one so like a snail-shell consisted of only one piece, while another had two, and the third seemed to be made of several little shells all joined together." "You are quite correct, my love, and all shells belong to one or other of three great divisions, distinguished by the number of pieces or valves of which they are composed; you know that, in Latin, ' unus' stands for one, ' bis' for twice, and 'multus' for many. This snail-shell, then, which, as you say, is made of one piece, is called a univalve. This, which, like the common oyster, has two pieces, is a bivalve; and this, which is composed of several parts, a multivalve. Now, Willie, let me hear if you can remember these three diffi- 
cult names ?" Willie repeated them correctly, and Miss Eldon advised him to write them down on his slate, to prevent his forgetting them before the next lesson. She also explained to him that the parts of every shell are known by distinct names, in the same way as the different parts of the human body are distinguished, as, arms, legs, teeth, \&c.; but she thought it better not to puzzle him with too many long words at first, and therefore proposed to teach him simply the orders of the Linnæan genera, hoping that he would be soon sufficiently interested in the subject to wish to conquer the remaining difficulties; she now promised that, after breakfast, she would take him to the residence of the poor fisherman she had mentioned, and that he should there purchase his first specimen. The little boy was delighted, and ran to communicate the pleasant tidings to his brother and sister. Ellen was just coming down stairs, for she too was longing to ask some important questions about her sea-weeds. But Miss Eldon saw that there was a string off Ellen's frock, and a button 
wanting on her shoe, and she knew that it would be wrong to let even useful and instructive pleasures interfere with necessary duty, so she told Ellen that she must wait until all these things were set right, and that then she should have great pleasure in giving her the instruction she wished. Poor Ellen! this was not the first time that her untidy habits had deprived her of an expected pleasure; untidiness was Ellen's great fault, and it had often given her trouble.

Most little girls and boys have some failing to which they are particularly liable, and unless they, and their kind friends, make a great effort to conquer it while they are young, it will increase with their years, and perpetually cause them sorrow. Miss Eldon knew this well, and so did Ellen, and therefore, although she looked very sorry and sad, she made haste to get her work-box, and, before breakfast was ready, the string and the button were both carefully replaced. It was a lovely morning, and at ten o'clock a bath-chair was at the door for Mrs. Carlton, and Ellen arranged the pillows that 
her dear mama might be able to ride pleasantly, and without pain or fatigue; and away they all went to the sands.

$\mathrm{Oh}$ ! how fresh and pleasant were the gentle sea-breezes, and how brightly and merrily the little waves danced and sparkled in the sunbeams! who could wonder that the hearts of the children bounded with happiness as they tripped along by the side of the pleasant water?

But surely there is a cloud upon one little countenance which generally looks the most joyous of the whole group. What can it be that makes poor Mary's face so grave and sad, and her usually light step so mournful and slow? Ah, little reader! you are thinking, perhaps, that some one has hurt her, or that she has broken her beautiful wax doll, which we had forgotten to say arrived just in time to accompany her to Ramsgate. No, no such thing; and indeed I am ashamed to tell you what really is the matter. Alas for poor Mary! although a very lovely and sweet little girl, generally speaking, she has a sad temper, that will come to trouble her sometimes, and like a 
dark cloud hide all the sunshine. Mary had wanted to wear her best gloves down to the sands, and her sister Ellen had very properly told her that the common cotton gloves were quite good enough for the purpose, and Miss Eldon had decided that the cotton gloves were to be worn; but Mary did not like to give up her own way, and she had worn a cross face ever since; and now, instead of running merrily about with her little basket and spade, she stood quite silent and sulky by her mama's chair. Mrs. Carlton was engaged in conversation with Miss Eldon, and for some time took no notice of little Mary, but at length she turned to her, and asked what made her so still and sad. "I hope," she added, "that my dear little girl is not out of humour."

Mary did not reply, and her mama, who knew that she must be very firm and decided, told her, that unless she saw her countenance brighten immediately, she should be obliged to send the nurse home with her. The child saw that she was giving pain to her kind mama, and felt really tired of being naughty, so she 
came and asked for a kiss, and said she would try and be a better child. Just as she turned round to follow her brother and sister, she saw something on the sand that attracted her attention.

"See, see! Miss Eldon, how fast it runs. Oh, do come and help me to catch it. Will it hurt me, will it sting, do you think?" "No, you may pick it up, dear; but touch it carefully, that you do not kill it. There, put it into your basket, and I will cover the top with my book, while you go and tell Willie that we have something curious to show him." Away tripped the little girl, and the children soon came crowding round the basket. "It is gone!" exclaimed Mary, in a tone of disappointment, when the book was removed; but no, the little gentleman had not escaped; there he lay in a corner, rolled up like a ball, very little larger than a pea.

"What stuff to call that a curiosity!" said Leslie, "why it is nothing in the world but a great woodlouse." "No, no," said Willie, who had been examining it attentively, " it is 
not a woodlouse, Leslie, though it looks something like one, but I really think I have found out what it is. May I guess, Miss Eldon?" "You may, my love, but I do not think you can tell me its name."

"No, not exactly its name, but it looks to me very much like one of the shells we examined this morning. See, it has all the little valves laid one over another; it is a multivalve shell, is it not?"

"Yes, my dear, it is a small specimen of the Chiton. Can you now remember the name of the animal that inhabits it?"

"It is a mollusk, I think, but I wish it had done with its shell, for I do not like the thought of killing the poor thing."

"We will not kill it, Willie, we will only look at it and let it go. I will give you the shell we saw this morning for your box, as I do not think it likely you will pick up an empty one here; they are not often found upon these sands. But the little thing is unrolling again, that we may see how cleverly he can move about his thick shell, which truly looks 
like a coat of mail. Chiton is a Greek word, which signifies a coat of mail, and I think the name well describes the shell, which generally consists of eight valves united by a membrane, or thick tough skin; and a famously strong defence it forms against the poor Chiton's enemies, for he lies like a ball at the bottom of the sea, while they swim unconsciously over his head.

"Now take the little fellow to the water's edge, and give him his liberty; and when we reach home, Willie, we will put the first multivalve shell into your box."

Mrs. Carlton did not remain more than an hour upon the sands, when Ellen and the nurse returned home with her.

Miss Eldon took Willie and Mary to find out the abode of the poor fisherman; this was not very difficult, as she had already made the necessary inquiries. They found him sitting at his door mending his nets, while a little girl, about eleven years of age, was on a stool at his side, polishing a large shell with a piece of leather. The poor man rose as they 
approached, and requested them to enter, desiring Mary to get the young ladies a seat. His wife came forward with an infant in her arms, and asked what kind of shells the young gentlemen would please to like?

"We wish to look at your small cabinet shells, Mrs. Lester; and although we only want one or two to-day, yet we mean to come and see you very often, as we are anxious to make our collection perfect; and I am told that you have some very suitable shells." The poor woman said, that she should be thankful to dispose of any she had; and opened a drawer that Miss Eldon might choose from them. She selected a few of the specimens she wanted; and asked in what way Lester obtained the shells and corals he offered for sale.

The fisherman told her that he was in the habit of going in his little boat to the vessels that came from distant parts, but did not always touch at the harbour; and then purchasing these articles from the seamen who brought them over, and who were glad to dispose of them at a low price before they landed. 
This he said he was often obliged to do in very stormy weather, when he was engaged in looking out for ships in distress, so that he was frequently out whole nights when the wind was contrary, and his poor wife sometimes feared that he would never return to her again.

The children were much interested in this recital, and would willingly have heard more, but Miss Eldon was fearful of trespassing on Mrs. Lester's time; so, promising to repeat their visit very shortly, they left the cottage.

When they reached home Miss Eldon told Willie, that she had now a specimen of all the multivalve shells, "which," she said, "you will remember is the smallest of the three divisions. You brought home a Pholas or stone piercer in your basket the other. morning, but yours was not quite perfect, as it had only the two large valves remaining. This, you see, is a very fine specimen, with all its parts complete. These

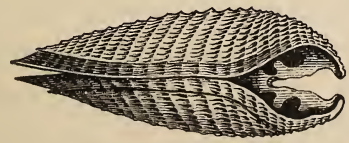

shells are generally found buried in the rock or 
lime stone, which the animal perforates when quite young, and which perforation he enlarges for his growth, and generally remains in as long as he lives."

"Now, Willie, look at these two shells, so very different from each other in form and appearance. You will be surprised to hear that they both belong to the same genus 'Lepas.' The mollusks which inhabit them resemble each other, and the shells are also alike in many respects. These with the long thin stem are called the Lepas Anatifera or Duck Barnacle. They are very wonderful little creatures, and have been known to affix themselves to ships in such vast numbers as to render them wholly unfit for sea. I remember once seeing a vessel brought into the dry-dock of this harbour to be repaired, that was completely crowded with these curious animals; they hung clustered about the hull of the vessel in thousands, and produced a loud hissing noise, by expelling the water from their peduncle, or stem. If we should be so happy as to procure some living specimens, I will preserve them for you in 
spirits, as they not only lose their beautiful purple and vermilion colour, but are otherwise much injured in drying. The stem sometimes attains the length of ten or twelve inches. The other shell is a large and particularly fine specimen of the Tintinnabulum or Bell Lepas. The shell, you see, is of a rich purple colour, shaped like a bell, and fixed at the base to a piece of rock; it is brought from the West Indies, and is called, in England, the acorn shell. Now place them in your box, and tell me the names of the three shells of the genus multivalve."

Willie repeated them correctly, and placed his specimens of Chiton, Lepas, and Pholas, in the little compartments provided for them. 


\section{$(40)$}

Chapter V.

EXCURSION FOR FOSSILS-SKETCH OF GEOLOGY-A STRANGER-HELIX-ECHINUS-A NARROW ESCAPE.

Mr. Carlton had been closely occupied in writing since his arrival in Ramsgate, and, much to poor Leslie's disappointment, had been unable as yet to take the anticipated excursion in search of fossils; so he was much surprised and pleased, one fine sunshiny morning, to hear his papa propose that they should start immediately after breakfast for their first trip. The happy boy was soon ready, and cook was ordered to prepare some substantial sandwiches, lest they should not return at the usual dinner hour.

They walked along the east sands for a considerable distance before they commenced their search, and Mr. Carlton took the opportunity of explaining to Leslie something of the origin and history of the science of geology, and of the class of objects of which that science treats. 
"A geologist," he said, " is a person who examines into the different materials of which the crust or outward covering of the earth is composed; for although our miners have excavated to a very considerable depth, yet they are unable to penetrate below a certain point, and we must consequently be content with examining that which is within reach, and it forms a very small part of the earth's substance. We are now about to undertake even a less portion of research, as we are going to study only that part of the earth's surface which contains fossils or organic remains; and the most wonderful fact of this branch of the science is, that we shall probably find the remains of creatures that once had life, but of which there is not now a living species, and these are frequently found buried at a considerable depth in solid rock, and have actually themselves become filled with the substance of which it is composed, only retaining their own peculiar formation. It is therefore probable that these rocks were once in a fluid state, and that in this form they entered and filled up every crevice of the shell. You will not be sur- 
prised to hear that some very curious and superstitious stories have been told concerning these remains by the ignorant, both of your own and former days.

"One beautiful kind of fossil, called the ammonite, was said to have been a snake, turned into a stone by a witch, and other large shells were supposed to have been the work of fairies; but in these days of scientific discovery much care and attention has been given to ascertain the truth, and render the science of geology more really interesting and available. When you are a little older I will obtain for you Dr. Buckland's work on the subject, which you will find instructive and highly amusing."

"But, papa," interrupted Leslie, " you say that the geologist only studies the crust or outward covering of the earth: of what, then, is the centre of the earth composed?"

"Of this, my boy, we can only conjecture; but from recent experiment and research it is supposed that it must consist of something far heavier than any known body, and that this, 
from extreme heat, is constantly in a state of fusion, like melted metal. This idea is confirmed by the lava which flows from volcanic mountains, and by the boiling springs which are found in various parts of our globe, so that, as Mr. Higgins tells us, in a very useful, introductory work, 'Strange as it may appear, we are walking over a vast caldron of intrumescent (mixed or mingling) rocks, and are separated from them by only a thin crust, which is sometimes broken." "

"Oh, papa, this is very wonderful, indeed. I am sure I shall like to study geology, if it will tell me about all these curious things: but is the science of any real use, papa?"

"Yes, it is truly valuable in many important cases; and the progress of the science, as regards mining particularly, has saved an immense expenditure, both of money and labour."

"Has it really, papa? I cannot understand that at all."

"Why, Leslie, in former times many a 
wealthy man was utterly ruined by the failure of mining speculations; for instance, he would purchase a piece of land, and employ many hands in sinking a shaft, merely from the supposition that it might contain coal or other minerals; and this idea was probably occasioned by some accidental circumstance, such as finding a small portion of the material on the surface, \&c. This, as you may suppose, frequently proved a failure, and resulted in absolute ruin to the speculator. Now, Leslie, suppose that the practical geologist can tell by an attentive examination of the surface of the ground what minerals are likely to be discovered there, and even the probable depth at which they lie-this is now the case-and you may imagine that it saves much expense and disappointment. But now for the cliffs, or we shall lose the object of our walk. You see the tide is going rapidly down, and we shall have several hours before it will be necessary to return."

"Papa," said Leslie, " what is the reason that the cliff, at yonder turning, looks so much 
more clean and white than the other parts, and there are no plants or grasses growing up the side?"

"Why, Leslie, we are indeed fortunate! there has been a large fall of cliff, and we shall have the advantage of being the first to look for the newly exposed fossils."

But Mr. Carlton soon found that he was mistaken, for when they approached near enough to look on the other side of the heap, they there saw a gentleman busily engaged in endeavouring to extricate a large fossil with the blade of a pocket-knife. Leslie was at his side in a moment, and offered his pickaxe to release the shell.

The gentleman rose and bowed to Mr. Carlton, who begged that he would accept their assistance, as he appeared to be unprovided with instruments. The stranger thanked them for their politeness, and the fossil was soon separated from the chalk. It proved to be a very perfect specimen of the genus Helix; and Mr. Desmond, their new acquaintance, begged that Mr. Carlton would allow Leslie to place it in 
his bag, as he already possessed many equally good, and had merely felt unwilling to allow so fine a fossil to be lost. "In Norfolk," he added, "they are very commonly found."

Mr. Carlton was pleased with the kind and gentlemanly manner of the stranger, and with some reluctance accepted the shell, which he said he should particularly value, not only as being the first in his collection, but also as it had proved the means of so pleasant an introduction.

"Now, papa, I think I have found something worth having," said Leslie, "for it is exactly like a fossil we saw at Mr. Knowles's last summer." "Yes, Leslie, it is an Echinus, one of the most beautiful, and at the same time one of the most common of the chalk fossils. The existing species is called the seaurchin, and a very curious and beautiful shell it is, covered sometimes with fine purple spines, and containing an animal of most singular formation-of a rich purple colour. I saw one dissected last summer, and was particularly astonished at the remarkable structure 
of the mouth, which consists of twenty-five pieces, moved by thirty-five muscles. (Mr. Kirby has given an interesting account of this singular mollusk in his Bridgewater Treatise on Animal Instinct.) In a short time they had collected several good specimens, and they then sat down under the shade of the cliff to take some refreshment. Mr. Desmond, having an engagement in the town, was obliged to return home; but, on parting, he gave Mr. Carlton his card, and expressed a wish that he might have the pleasure of meeting him again.

The fossil bags were already so heavily laden that our adventurers were not inclined for a very extended ramble; they, however, reached Broadstairs, and Leslie picked up a few weeds and shells for Ellen and Willie. They then bent their steps homewards, as the tide was rapidly returning. Their walk was a very pleasant one; the noonday heat had passed, and the air was cool and refreshing; a recent change in the wind had released the vessels which had long been detained in the 
Downs, and now the ocean was covered with snowy sails, as the gallant ships passed majestically onwards to their several destinations.

The water was coming in so fast that they were at length obliged to quicken their pace, and it was fortunate they did so, for there was but a narrow foot path left between the tide and the last jutting cliff that is washed at high water. After passing it, they again walked leisurely along the level sands, when they perceived a man running violently, and shouting, as he came, to some persons apparently behind them; they looked round, but seeing no one, they hastened on to learn what was the matter. The man still shouted and pointed, and, when he reached Mr. Carlton, with difficulty made him understand that some one had ventured beyond the point, and was in danger of being drowned by the flowing tide.

"Oh, papa, let us go back," said Leslie, "and see if we can help to save them."

"No, my boy, to rescue them here will be impossible, run instantly to the pier, and order a boat. Say there are persons in danger at the 
East Cliff point." Leslie threw down his bag, and darted away like an arrow, and Mr. Carlton turned to speak to the man, who was already knee-deep in water. He, however, soon found that to stem the waves was impossible, and he gave up the effort in despair. "Oh, sir," he said, "'tis poor Jem Lester's children, and it will go nigh to killing his wife if they are lost. I heard quite by accident as they hadn't come home, and then I remembered seeing them go along here after tide had turned. Please God Nancy may have reached the inner creek; the water wont be above her waist there, if she does but hold the poor baby tight." Mr. Carlton remembered to have passed a girl with an infant in her arms soon after he left Broadstairs, but supposing she belonged to that place, and would return in good time, he had not thought it necessary to warn her of danger. They could now distinctly hear screams for help, mingled with the low wailing of an infant. It was a terrible moment; they could do nothing but shout to the girl, and tell her that help was coming, but they 
could scarcely hope that their voices were heard, as the wind blew in a contrary direction. At length they saw the boat shoot swiftly round the pier-head; two men were rowing, and Mr. Carlton perceived with concern that Leslie was with them. He had forgotten to tell the heedless boy to return to him after giving the alarm, and he now trembled lest any mischief should arise from his impetuous spirit. The men rowed as rapidly as possible, but it seemed a long weary time to those who were so anxiously watching; at length it rounded the point, and all was breathless expectation. The wind was brisk, and the sharp masses of rock rendered it a difficult matter to approach the shore.

Mr.Carlton knew that it was an enterprise of danger, and for the few moments that the boat was out of sight he offered a silent prayer that God would preserve his boy, and save the lives of the poor children.

“'They've picked 'em up any way, dead or alive!" exclaimed the man as he again caught sight of the boat, " and the young gentleman, 
bless his kind heart, is helping to warm the poor baby; he has taken off his own coat to put round it."

It was, as the man said, with great difficulty they had succeeded in getting the children into the boat; the girl had sunk into instant insensibility, and they had some trouble to disengage the baby from her grasp. Leslie now held it carefully in his arms, and the men rowed as fast as possible to the landing-place.

Mr. Carlton and his companion hastened forward to send for medical aid, and order hot water at the nearest baths, and thither the little sufferers were immediately conveyed. Leslie would not relinquish the baby until he placed it in the hands of the surgeon, who promptly applied the usual remedies. They soon had the satisfaction to hear that little Nancy was likely to recover, although, in the infant, animation was totally suspended, and life appeared to be.extinct. Their mother was with them, almost distracted with grief; and $\mathrm{Mr}$. Carlton, fearing their prolonged absence would excite uneasiness at home, and anxious that 
Leslie should change his wet clothes, hastened thither, promising Leslie, who was intensely interested in the recovery of the children, that he would send down in the evening to make further inquiries.

They had much to tell when they reached home, and great was the sorrow expressed by the children when they learnt the distress at the fisherman's cottage.

Miss Eldon kindly promised to go immediately after tea to learn every particular.

"Oh, do, Miss Eldon, and pray take a shilling of mine to buy something warm and comfortable for them," said Willie; "poor little Nancy must want it after being so long in the cold, cold water." "Yes," said Mary, "and my sixpence too, please, Miss Eldon, for perhaps poor Nancy has only got her wet frock to wear; for although she was so very clean and tidy when we saw her, yet her clothes were old, and she had hardly any shoes on her feet." It was settled that Ellen should accompany Miss Eldon on her errand of kindness, and she was soon busily engaged in preparing 
wine, gruel, and other comforts, for the poor people.

It was late when they reached the cottage, but great was their pleasure and surprise to find Mrs. Lester seated by the fire, with her living baby in her arms.

"Ah, madam," she said, in reply to Miss Eldon's inquiries, " the doctors had wellnigh given it up, but it wasn't so easy for a mother to do so, and I begged and prayed them to wait a little longer, while I warmed it in my bosom; and at last one of the gentlemen thought he felt a little beating at its wrist, and soon after he sighed, and you may think, madam, how thankful I am to have my poor little Harry again. But they say that even now I must take the greatest care of him, for he was always main delicate, and I never thought to raise him."

The baby's face was very pale, its little eyes were dim, and Miss Eldon almost feared that the poor woman's hopes were revived, only to be blighted again. She, however, gave her a jar of gruel, which she desired her to warm, 
and administer in small quantities, both to the infant and poor Nancy, who was asleep in an adjoining room. Ellen took some other little comforts from her basket, and gave the poor woman a few shillings, with which to purchase a new gown for Nancy, as soon as she should be well enough to wear it.

Miss Eldon talked very sweetly to Ellen, as they returned home, about the uncertainty of life, and the necessity of constant preparation for death, seeing that it surrounds us on every hand, and we cannot tell in what form it may be sent to summon us away. "How little," she said, "did poor Nancy imagine, when she started for her walk this morning, that she should be so suddenly called to the very brink of the grave! She has escaped, it is true, by the kind providence of God; but had not the poor fisherman accidentally caught sight of her, she and the dear baby would undoubtedly have been drowned. I trust, my love, that neither Nancy nor my dear little pupils will forget the lesson they have learned to-day, 'In the midst of life we are in death." " 


\section{$(55)$}

\section{Chapter VI.}

\section{THE Class BIVALVE.}

"Mrss Eldon! I began with the multivalve shells. Will you be kind enough to tell me why? In my little book univalves are described first, and multivalves last."

"They are generally so classed, Willie, but it is not of much consequence, and I thought it would be pleasant to you, as a beginner, to make yourself acquainted with the division that contains the smallest number of genera first, because you would the sooner feel that you had accomplished something."

"Oh, yes, ma'am, I see quite well; and now, if you please, I am ready for my last two specimens of class bivalve."

"I have them here in my work-box for you, Willie, but you must earn them by giving me a short account of what you have learned of this division, and the names of the shells belonging to it." 
Willie put down the shell he was holding, and opened his box, that he might point to each specimen as he named it; he thus began:

"The class bivalve is known by each shell being composed of two parts or valves, as the name signifies. These two parts are connected together by a ligament of a thick horny substance at the hinge or part which lies at the back of the mollusk; the hinge is generally furnished with one or more teeth; by the number of these, and the shape of the shell at the hinge, one genus of the class is distinguished from another. The mollusks which inhabit them have not a distinct head, nor any eyes; the only sense they appear to possess is that of touch."

"Very well remembered, Willie! Now tell me the names of the shells belonging to this division."

Willie.- "First, the Mya, or gaper, one species of which, the Mya margaritifera, is celebrated for producing fine pearls; and do you know, ma'am, I read the other day that pearls are thought to be occasioned by a disease of 
the animal, which causes it to secrete part of the beautifully transparent substance with which it lines its shell?"

Miss Eldon-"So it is said, my dear, and I have heard that there is still a large pearl in the British crown produced by one of these Myæ in the river Conway."

Willie._" Then comes the Solen, or razor shell, so called, I suppose, from its length and shape; then the beautiful Tellina, with its delicate pink and white, putting one in mind of lilies and roses. No, it is like a rose, Miss Eldon, that beautiful rose Ellen brought mama, which you said was called the York and Lancaster."

Miss Eldon.-"Well, its colours are something like it, Willie, and one species for this reason is called the 'rosy tellen.' But go on, or we shall never get to the end of the list."

Willie.- "Next is the Cardium, or cockle, a heart-shaped shell, and a very common one; the Mactra, or kneading-trough; the Donax, or wedge shell."

Miss Eldon.-“Stop, Willie, I will tell you a 
story about the Donax. The mollusks which inhabit these shells are a great attraction to the sea fowl, as they are a food of which they are particularly fond; but the shell is so thick that they cannot break it with their beaks, and they therefore carry it to a great height in the air, and let it drop upon the hard rock, which crushes the shell, and enables them to make a prey of the inhabitant. They have even been known, when the little animal has opened his shell for a moment to take in air or food, to drop a pebble between the valves to prevent their closing, and then dart down to secure their prey."

"That is very cunning and ingenious," said Willie: "and now comes the Venus, so much used as an ornament by the women of North America; then the Spondylus, or thorny oyster; and the Chama, or clamp,-and you promised me a story about this, too, Miss Eldon."

"I did, my dear, and I think when I have told it you, you will love the Chama better than all the other shells in your collection. 
"Yours is the smallest specimen I almost ever saw, but these shells sometimes attain an enormous size; I have myself seen a single valve, which it would require a strong man to lift from the ground, and I have heard that above a hundred men have been furnished with a day's food by the mollusk of a single shell. Well, if I recollect rightly, it was when the Moravian missionaries first went to the South Seas, that there was a dreadful famine in the islands, and the poor men were sadly persecuted, - not even allowed to share the little food that yet remained to the natives. They were reduced to such extremity that they sucked the moisture from the very ground to preserve life, till at last one of them discovered on the shore a large shell of the Chama genus, and,

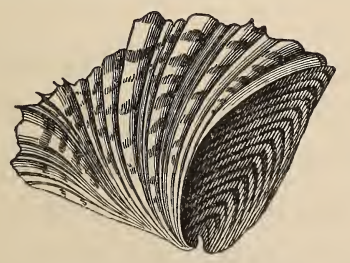

quite ignorant whether the fish would afford them proper food, they began to eat it even in 
its raw state; they found it nourishing, in time almost agreeable; and these mollusks formed their only support for a considerable length of time."

"Dear me! how very wonderful!" said Willie; "and I dare say they were very thankful to God, for giving them food of any kind when they expected to be starved to death. Go into your corner, pretty little shell, I shall not forget your story. Shall I go on, ma'am ?"

Miss Eldon desired him to do so, and he then continued. "The Arca, or ark; the Ostrea, or oyster, including the scallop, which was formerly worn in the caps of pilgrims, who had crossed the sea to visit Jerusalem; the Anomia, or Antique Lamp; the Mytilus, or muscle; and the Pinna, or sea-wing, which is the last of the bivalves."

"You have well earned your shells, my dear Willie, and I have been fortunate enough to meet with a beautiful Pinna for you. Your papa was so kind as to purchase it at the lighthouse last evening. Look at the delicate structure of the shell, and see this tuft of silky fibres at the 
end; it is called a Byssus; by it the animal fastens itself to the sand or gravel. On the coasts of Sardinia and Corsica these fibres are spun into silk, and woven into different articles of manufacture. Now run to play, Willie, and to-morrow you shall begin univalves; but you must not read another word to-day, little studious boy, or I shall have those poor cheeks looking paler than ever." 


\section{( 62$)$}

\section{Chapter Vil.}

ELLEN'S SEA-WEEDS.

"Dear mama! may I sit with you this morning while I attend to my sea-weeds?" said Ellen. "Miss Eldon has allowed me to devote the whole morning to pressing them, because she did not find any of my boxes or drawers out of order when she examined them yesterday."

"With pleasure, my dear child. I am truly glad that you are improving in this important particular. It is the only thing that gives me pain in my dear Ellen's character, and I am truly obliged to Miss Eldon for the trouble she so constantly takes to get rid of it."

"And so am I, dear mama, for I am sure I shall be much happier when this terrible fault is quite conquered."

"You will indeed, my love; and now, as I am stronger and better, I think you may ask Miss Eldon to come with Willie and Mary, that I 
may have the pleasure of seeing how you are getting on with your interesting studies; and as dear Leslie is gone to Dover with papa, we shall enjoy spending a long day together."

The summons was soon obeyed, and Mrs. Carlton was pleased and surprised to find the progress the children had made in their several pursuits. She looked at Willie's nicely arranged shells, and at little Mary's basket of treasures, and then examined some of the weeds which Ellen was so busily pressing.

"Now, Ellen," she said, "fetch another dish, and try if you can teach mama how to press sea-weed. I think I should like it very much, and Miss Eldon fancies that I shall derive benefit from their effluvia.

"I do indeed, ma'am," said Miss Eldon, "and rejoice that you are able to commence; I have seen so much benefit arise from the pursuit, that I quite hope it will prove of equal service to you."

"Did you ever know any person better in health from pressing sea-weed, ma'am?" said Ellen, incredulously. 
"I have indeed, my dear; I have myself a friend who I believe owes much of the health she now enjoys, under the blessing of God, to this pleasant employment. She suffered much from a low nervous disease, combined with a depression of spirits, that made her friends seriously uneasy. Medicinal treatment, and change of air and scene, were resorted to without any apparent benefit. At length she began to take some interest in the beautiful sea plants which her children brought from time to time from the shore; a friend taught her how to preserve them, and she daily spent some hours with her pressing apparatus before her: she felt an interest in the study itself, which drew her mind from her sufferings, and excited her fancy; and to this, with the healthful smell of the fresh gathered sea-weeds, her friends thankfully ascribed her present restoration to health. A handful of newly collected weed is also of much service in purifying the air of a sick chamber."

"Oh!" said Ellen, "this is delightful news indeed; I shall love my pretty plants better 
than ever, if they are really of use to my dearest mama." So she went joyfully into the kitchen to procure a white well-dish, and placed it on the work-table at her mama's side, filling it carefully to the very brim with fresh spring water. She then took some of the plants she had already washed and sorted, from her own dish, and putting them into her mama's, began to show her the method of expanding them, which Miss Eldon had already communicated to her.

"This plant, dear mama, is the Delesseria alata; and because it is so thin and fine it must be preserved upon oiled paper, else it will adhere, and probably tear in removing."

Ellen then took a pointer, which she had made by fixing a large darning needle into a stick of cedar; and floating the plant on the surface of the water, she slipped the paper underneath, and gradually drew it out on to the side of the dish, directing the position and form of the branches with the pointer, as she did so. It was then placed in blotting sheets, and these were again laid within folds of coarse 
brown paper, and the whole placed under the hearth rug to press and dry.

Several beautiful specimens were thus preserved; and some of Ellen's weeds, already sufficiently dry, were removed from the paper on which they had been expanded, by passing the pointer under the principal stem, and carefully detaching the branches, by gliding it smoothly under them.

When Mrs. Carlton felt tired, she requested Ellen to take her portfolio, and tell her the names of some of the weeds she had collected. "I will, mama, as far as I can remember them; but some of the words are very troublesome to recollect, and Miss Eldon does not think I am yet old enough to arrange them according to their proper classes, so that I am now merely learning their names, and the principal characteristics by which they are distinguished."

"Well, dear, I am sure Miss Eldon is right; so now let me hear how many of these difficult names you can remember. Suppose we begin with the larger weeds. Here are two very thick and coarse." 
"Yes, mama, they are called the Laminaria digitata, and the Laminaria saccharina. I have taken a small part of each plant, for they are so large that it would be impossible to preserve the whole. The saccharina derives its name from the sweet flavour of the leaves when bitten or crushed.

"This plant with the notched edge is the Fucus serratus, and that with the little broken air-vessels the Fucus vesiculosus, so useful in making kelp. This dark olive green is the Fucus nodosus, and it is distinguished from the vesiculosus by the air-vessels being formed in the centre of the stem, instead of at the extremity of the frond or leaf.

"Miss Eldon tells me that in Wales, where it is of very common growth, she has found an air-vessel so large as to make a tolerably sized smelling-bottle. It there assumes a very beautiful appearance from the effect produced by a fine delicate plant that grows upon it; I forget its generic name, but it is called a parasite, because it has its root upon another plant. You see, dear mama, that my specimen has a 
small piece of this little weed attached to it; but I should think, from Miss Eldon's description, it must be truly beautiful, as she found it on the coast of Wales."

"It is indeed, my dear," said Miss Eldon. "I found a piece on the shore at Milford Haven, which surpassed in beauty anything that I have ever seen among the Algæ; and the Polysiphonia fastigiata, the parasite, of which you have forgotten the name, hung from it in massive festoons of the most delicate and beautiful structure. I have found it impossible to give any idea of this beautiful appearance in drying the plant, although I have made many experiments for the purpose. It shrinks to half its size in preserving."

"How much I should like to see it in that beautiful state! did you find the coast very interesting in these productions, Miss Eldon?"

"I did indeed, ma'am, although on my first arrival my friends assured me that it was entirely barren, and that I should find nothing but the most coarse and common weeds; and I assure you I was laughed at not a little for my many scrambles over the sharp and rugged 
rocks, but I was amply rewarded by procuring some beautiful specimens that I have never equalled elsewhere. I obtained one plant which I value very much, and have not yet named, being unable to find its description in any work on the subject that has yet come within my reach."

"Dear me, how much I should like to see it!" said Willie, "is it very singular in appearance?"

"When I first brought it from the shore it looked like a bunch of dark green Indian-rubber cups, very much resembling in shape the socket of an acorn: but I shall hope some day to have the pleasure of showing it to you; I have already written for my collection, that Ellen may have the pleasure of comparing her specimens with mine."

Mrs. Carlton fully participated in the children's pleasure at this intelligence, for she already began to feel an interest in Ellen's favourite study. The little girl went on with her description.

"There, mama, is a very small piece of the Fucus canaliculatus; it is rarely found here, 
but Miss Eldon tells me that it also grows abundantly on the rocks at Milford Haven.

"Those are all the black weeds I have gathered, mama : now for some of my favourites! and here is my greatest treasure; dear Leslie brought it me from Margate jetty. It is called the Delesseria sanguinea, and a very beautiful

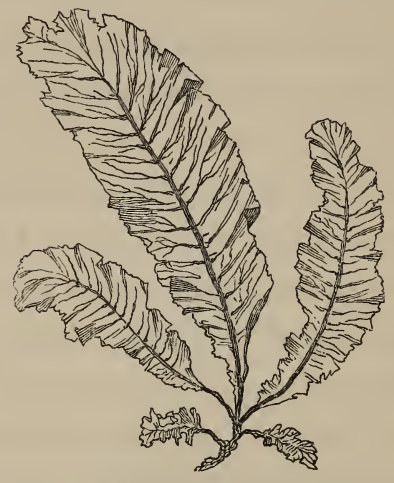

specimen it is. I think, mama, its colour is as bright and clear as that of your favourite rose; and see the delicate branching veins, making it look like a red palm-leaf or a crimson feather !"

"It is indeed, my love, a most exquisite specimen of the skill of the great Creator. I had no idea that the ocean produced such splendid tints and forms. I am delighted to think that my dear children will have the advantage of 
learning in early life to look to the works of nature for instruction and amusement."

"It is very delightful, mama. Now we all long for walking time to come, sure of finding something new and beautiful. How unlike the dull tedious walks we used to take, when you were ill, with poor nurse, who, although very kind and good, seemed always as glad to take us home as we were ready to go! But I will make haste and finish, for you are tired, mama, and I can hear cook jingling the dinner-plates already. Oh, how quickly this happy morning has passed!

“This pink plant, with its spreading branches, is the Delesseria alata, the same as the one you have just expanded. This, with the short thin fibres branching from the stem, is the Delesseria plocamium, one of the most common of this beautiful order. Then come two Rhodomenias, ciliata and palmata; then the Chondrus crispus, which I found quite buried in the sand after the storm last week. See, mama! it is left loose from the cord that we may hold it to the light. Is it not a beautiful purple? Here is another pretty purple plant, but it is so thin 
and delicate that I am almost afraid to touch it; it is called the Porphyra laciniata. This green, so like it in texture, is the Ulva latissima; this, like a bunch of pressed grass, is called the-the-"

But here poor Ellen was obliged to stop; she could not remember the difficult name.

Miss Eldon told her it was the Enteromorpha compressa, a common and beautiful weed eaten in the Sandwich Islands.

"Oh, yes! I remember now," said Ellen; " but I think I must not show mama any more until I have learned their names correctly."

"You have recollected these that we have examined exceedingly well, my dear, and have afforded me a very pleasant morning's amusement; and now, Ellen, I shall have great pleasure in giving you a little present, which I know you will value, and which you have really deserved by your diligence and attention."

It was a little botanical microscope, well adapted by its size and form to assist Ellen in the examination of her sea-weeds. It had a brass screw, by which she could bring it to a proper focus of sight, and this was connected 
with a glass, so smooth and polished at the edge that it could be placed upon the plant without injuring it, which was thereby rendered steady and firm, so that the object could be examined at leisure.

Ellen was of course much delighted, and after thanking her mama very affectionately, she sat down to amuse herself with her new acquisition. She looked at some of the plants, of which she had not yet learnt the narnes; for Ellen made it a rule not to put any into her portfolio until she had studied their formation so well that she thought she should be able to recognize them when she found other specimens on the shore.

"Oh, mama!" she said, "I did not think it possible that anything could make my seaweeds appear more beautiful, but they seem to be almost new to me now I see them through the glass; they are so curiously marked and jointed, and the colours are so bright and various; and look, dear Miss Eldon! I do think I have made a discovery: see, ma'am, the curious little knobs covering all over this small piece of weed!" 
Miss Eldon smiled, and laid down her work.

"I am glad that you have made the discovery, Ellen! I quite hoped that you would do so; for those little 'knobs,' as you call them, form a very important feature in the study of the Algæ. This weed is, as a naturalist would term it, in a state of fructification, that is, it is now bearing seed, in the same manner as terrene* plants produce their fruits or seeds in their proper season.

"The blossom of an Alga is imperceptible, and the seeds are extremely minute; they are, nevertheless, perfect in their formation, contain the germ of new life, and answer the important purpose of reproducing their species. The airvessels so frequently found in the larger plants were formerly classed as seed-pods. This seems a strange mistake, as they do not contain anything bearing a resemblance to fruit, but appear merely to answer the purpose of floats, for keeping the masses of weed sustained on the surface of the water. But Mary is calling us to dinner, so put away your sea-weeds for the present!"

* Plants that grow on the land. 


\section{$(75)$}

\section{Chapter VIII.}

WALK TO THE WEST SANDS-THE LEPAS, BARNACLE-THE CEMENT HOUSE-THE WRECK-A VISITOR-LESLIE'S STORY - AN ACCIDENT - DOVER CASTLE - THE DEBTOR'S GAOL-FOSSILS-PLEASANT TIDINGS.

After dinner Mrs. Carlton proposed that Miss Eldon should accompany the children for a walk, while she took her usual rest, and that they should then drink tea together, and hear what had befallen the travellers, who were expected to return about six o'clock.

The proposal was a pleasant one to all parties, and away went our little friends as usual to the sea shore.

Miss Eldon proposed, that, as the tide was low, they should bend their steps to the West Sands, where she thought that Ellen might possibly meet with some valuable plants, especially as the wind had been blowing in a southwesterly direction, and the tide would probably have washed up something to interest them. They walked along the back of the basin, 
passed the foot of Jacob's Ladder, and, with some stumbles and slips, reached the sands at last. These sands under the West Cliff are at all times rough and uncomfortable to the feet, but they were rewarded for the tiresome walk by discovering some plants they had never seen before, and which Ellen knew would afford employment for her pointer for many succeed- * ing days.

They were on the point of leaving the shore, when Willie caught sight of his old friend the fisherman, who was carrying something in his hand, which much excited his curiosity. He ran to meet him, and having ascertained that the two children were rapidly recovering, begged that he would tell him what he had found.

"Indeed, young gentleman," said Lester, "I don't know rightly as I can tell you, tho' I've found them afore, on the bottoms of ships and the like, but I've heard the gentlefolks call 'em barnacles or bannacles, or the like o' that; but I shall be very glad to sell 'em, sir, if you've a mind for them."

Miss Eldon soon made the arrangement, and 
after the children had curiously examined their purchase, she desired Lester to leave them at the Terrace as he returned home.

They were indeed the real, living Barnacle Lepas, attached to a piece of wreck, which had doubtless been recently washed ashore. The beautiful creatures hung closely together, attached to the wood by their golden and purple stems, and making a distinct hissing noise, as they put forth their delicate feelers in search of food. The children seemed almost unwilling to part with their new possession, but as Miss Eldon told them that they would keep in perfect safety until their return home, they cheerfully continued their walk.

They proceeded along the Cross Wall, and stood for some time watching the labourers, who were preparing the massive blocks of stone used in repairing the pier.

Little Mary picked up a shining fragment which fell at her feet, and asked Miss Eldon if she did not think it very pretty; "much prettier," she added, "than the dirty, dark stones in London." 
"It is, my dear, a very beautiful stone; it is called granite; and as that is a nice piece, you may put it, in your basket, with the treasured piece of sand-stone, and if you have patience to keep them until you grow a little older and wiser, I will teach you something about these pretty things."

"And what shall I be, Miss Eldon, when I know all about them? Will there be a curious long name for me too?"

" $\mathrm{Oh}$, yes, there will indeed! ask brother Willie if he can tell you what it will be."

"You will be a little mineralogist, Mary : and look! here is another pretty piece of granite for you."

They were now passing a small building in which a steam-engine was busily at work; and Willie asked permission to run to the door, to take a peep inside.

There was a kind, pleasant looking old man standing just within, and he very politely asked Miss Eldon to enter, and said he would show the young gentleman what was going on. "This is called the Cement House, sir," he said, 
addressing Willie; "and this engine here is grinding the limestone, sand, lava, \&c., of which the cement is made."

"Lava!" exclaimed Willie, "what the hot, burning fluid, that flows from volcanic mountains?"

"The same, sir," said the old man; "this that we have here is brought from Mount Etna: when cold it becomes quite dry and hard, and in that state it is brought to England and used as I am now telling you. The cement is made use of to fasten together the great blocks of granite, of which this harbour is built."

The kind old man picked out several pieces of pretty sparkling crystals and fragments of shining spar, which, with some of the lava, he thought would please the children; and, after thanking him for his kindness and good-nature, they went on.

They were soon stopped again by seeing that the drawbridge over which they were about to pass was opening to admit a shabby looking vessel, without masts or rigging, which was being slowly conveyed into the inner basin. 
A great many people were collected, and as there seemed to be much bustle and excitement about the bridge, Miss Eldon made inquiry of a sailor who was standing by, and found that it was the wreck of a foreign brig, which had lost rudder, masts, and every possible means of control; and which, after having been lightened of its cargo, and drifting about for many weeks in imminent danger of being dashed to pieces against the rocks, had been at length brought into the harbour by an English merchantman.

"Indeed, ma'am," said the sailor, "I am told that the poor fellows who are left-for many of them were washed overboard when the ship struck-have been without food or water for many days. See there, ma'am, one of them has leaped ashore already, and is running off to get something to eat."

It was too true: the poor half-starved creatures were positively wild for food; the humane captain of the vessel had not dared at present to give them more than small quantities of gruel, and other light and unsubstantial nutriment, knowing that the effects of solids or sti- 
mulants in their weak condition, would necessarily prove fatal. It was painful to see their hungry and haggard faces, and be obliged to deny them that which they so eagerly craved. More than one leaped off the vessel before it had cleared the bridge, and ran towards the public houses to satisfy their hunger, but they were followed and brought back again, and the children could hear the gentlemen on board promise them they should have more food directly the surgeon thought that they would be able to bear it.

Willie's eyes were already swimming with tears, and Ellen could see that the old sailor drew his sleeve hastily across his face as Miss Eldon turned to ask him if he thought that the poor men would be properly taken care of.

"Yes, ma'am," he said, "there's no fear of that now; but it almost makes a baby of me to think what the poor creatures must have suffered, while we at home, who have had plenty to eat and drink, have forgotten perhaps to thank God for sending it."

"True, my good friend, very sadly true, I 
fear," said Miss Eldon; "but I hope that we shall have learned a lesson this evening, not soon to be forgotten, a lesson of thankfulness to God for those mercies which we are sometimes in danger of slighting because they are so constantly given to us."

The old man touched his hat respectfully as he wished them good evening, and as the bridge was now closed, they once more proceeded on their way.

They passed through the town on their return, in order to procure some spirits of wine and a wide-necked bottle in which to preserve their beautiful specimens of the Lepas, and were not a little surprised, when they arrived within sight of home, to find that Mr. Carlton and Leslie, accompanied by a stranger, were already on the steps.

Leslie sprang to meet them, and seemed intending to give them a full account of his adventures before they got inside the house; but Miss Eldon advised him to wait until they were rested and had taken tea, when all would be delighted to listen. 
Leslie readily acquiesced. "But," said he, "Mr. Desmond has come home with us, and is going to remain till bed-time,-is it not delightful? Pray make haste, Ellen, and take off your bonnet, we shall have such a glorious; happy evening!"

The children were all permitted to remain in the parlour to tea at Mr. Desmond's request, and, after the tray had been removed, Mrs. Carlton asked for some account of their visit to Dover.

Leslie was about to reply immediately, but he fortunately recollected that there were older and wiser people in the room than himself, and he waited for his papa or Mr. Desmond to speak first.

" I think Leslie must tell our story," said Mr. Carlton, " for we have had a very pleasant and agreeable visit, and I should like to know how much he can tell us of what he has seen and heard; but will this be quite pleasant to our friend?" Mr. Desmond assented immediately, and Leslie began.

"You know, dear mama, we were rather late 
in starting this morning, as the weather looked unsettled, and papa could not quite decide upon going; we were therefore obliged to run fast all along the pier, and only got on board as the bell had finished ringing.

" I soon caught sight of Mr. Desmond, and told papa, and we were very glad indeed to find that he was going merely for the day's pleasure, and that we might hope to enjoy his company. The sea was a little rough, but we went along very pleasantly until we came within sight of the harbour, when the captain told us that the tide was too low for the vessel to get in immediately, and that we must either wait on board for another hour, or land in a small boat. Papa decided upon the latter course, and we were soon comfortably seated in one of the rowing boats that was already lying alongside.

"We were just about to start when we heard a frightful cry from many voices, and instantly saw a gentleman struggling in the water; it was fortunate for him that the steamer had been stationary for some time, or in all probability he would have been drawn under the 
paddle-wheels and drowned; but he seemed to have a great deal of presence of mind, and tried to keep himself afloat until he was rescued by some of the rowers, so that he happily escaped with no further injury than a thorough wetting."

"And how did he get dry and warm again?" said little Mary, who was listening very attentively.

" Oh the boat very soon reached the shore, and the gentleman went to an hotel near the landing-place, and borrowed some clothes while his own were dried. Papa called to inquire for him, and found him quite well, and able to laugh at his adventure; he said, that the accident had occurred from his having missed the boat, which had been moved by a wave just as he was stepping into it. As we were walking towards the heights, papa related a story which I think would much please Ellen and Willie: may I tell it, mama?"

"Certainly, my dear; I am glad that you have not forgotten it."

Leslie. - "Sir Walter Scott relates, in a 
journal which he kept during a voyage to the islands in the north of Scotland,* that one day a boat came off to them from the Fair Isle, an island lying between Orkney and Zetland. It was a very slightly built little skiff, and appeared unsafe and crazy. One of the sailors, on board the large vessel, remarked to the steersman, 'that he must have great confidence in Providence to go to sea in such a vehicle.'

“ ' Yes,' said the poor man, ' and without that confidence I would not go to sea in the best tool (or vessel) in England.'"

The children were delighted with this story, and Willie said, he hoped he should always think of the poor islander when he was in any danger.

" Do so, my little fellow !" said Mr. Desmond, kindly patting his shoulder; " and remember that without the kind and watchful care of Providence our best efforts at selfpreservation must be utterly vain : always think of that beautiful text, ' What time I am afraid

* Lockhart's Life of Sir Walter Scott. 
I will trust in Thee.' But we are interrupting Leslie, and I see he is impatient to go on with his story."

Leslie. - "We soon reached the top of Shakspeare's Cliff, and papa held my arm while I looked over the edge on to the waters below; the height was so great that I felt quite giddy, and was glad that papa had not allowed me to venture alone. We sat down on the grass, and took our luncheon, and, after I had gathered a nice bunch of wild flowers for Mary and Lucy, we started to visit the Castle. It would take all night to tell you of the curious things we saw there. We walked all round the edge of the deep moat, examined the draw-bridge, and looked at the thick walls and massive windows of the building itself; but what astonished me most was the immense piles of cannon balls and shot, of various sizes, and one monstrous cannon called 'Queen Anne's pocket-piece.'

"There were several other immense pieces of ordnance that had been used or taken on memorable occasions, and a very talkative old man, who accompanied us as guide, told us 
their names and histories. He pointed out the gunpowder magazine, which is underground, and then conducted us to an immense well, where a great many men are employed at a time in drawing water. One bucket is drawn up while another is lowered.

"As we were coming away from the Castle we were surprised to hear a small bell ring sharply at our side; we turned, and saw that we were passing the Debtors' Gaol, and we could distinguish the hands of the poor men thrust through the iron bars of the window, to pull the wire of the bell, which is hung at the gate just over a small money-box, on which is written some such words as "Remember the poor debtors;" and papa says, that the money thus collected is divided among them, and appropriated to the liquidation of their debts. We all put something into the box, and then the men rung the bell again, as if to thank us.

"As we walked over the fields, on our return, we met a man who offered a very large collection of fossils for sale. We were glad of this, and papa purchased several very fine spe- 
cimens. Some of them were white, such as those that we find in the chalk here; others were evidently taken from beds of clay; others, again, were dark, and looked like metal, while some appeared to be completely turned into stone, and might have been taken for common flints, but for their exact and sometimes singular shape. We also bought some copper and iron pyrites, which are very curious. Two of them papa values much. One is shaped like an apple, another like a potato with a large nail thrust through the centre; these the man said were brought from the fossil bank at Folkstone.

"The pyrites, both iron and copper, are very beautiful when broken, and look bright and glittering like gold. I will show you some of them if papa will allow me."

"We will examine them all presently; but, Leslie, you have forgotten to tell mama of the great treasure you procured for yourself."

"Now, papa, I know you are laughing at me," said Leslie, "for you have looked and 
smiled so cunningly every time you have spoken about it."

"Well, Leslie, bring it here, and let me look at it. What did the man tell you it was?"

"He said, papa, that it was a piece of Shakspeare's Cliff, containing a great quantity of beautiful fossils; and I do think they are very pretty,-mama, do not you? See how very perfect some of them are, and how many are clustered together in this small piece of cliff."

"I cannot dispute that the fossils are very good, Leslie, but I doubt very much if any small piece of Shakspeare's Cliff ever contained naturally so many in a bunch; but fetch me a basin of hot water, and we will see."

The water was brought, and the supposed piece of cliff, as Mr. Carlton had foreseen, melted the moment it was placed in it, the fossils falling immediately to the bottom of the basin.

Leslie looked rather grave as he saw his treasure vanish so quickly away; but he soon joined in the laugh, when his papa explained to them that the fossils had evidently been 
purposely stuck into a piece of wet clay moulded by the hand, and in which they were likely to attract attention from their number and variety; and that, therefore, they would be much more valuable in their own simple form, and placed singly in the collection.

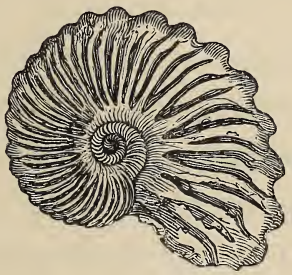

"I have been more fortunate with my own purchase," said Mr. Carlton; "for I have obtained a very fine specimen of the Cornu Ammonis: it was brought from Lyme Regis, in Dorsetshire, and is, I think, the handsomest I have ever seen. Can you surpass it, Mr. Desmond?"

"I think not, sir. I have a fine one in my collection, but this has been well cut and polished, and is beautifully crystallized in some of the chambers. I shall be very happy to give you an opportunity of judging 
for yourself when you pay me the promised visit in town; and I hope some of my young friends here will accompany you. I have a fine cabinet of shells, which will, I think, please my little friend Willie."

"I shall feel great pleasure, indeed, in accepting your kind invitation, sir," said Mr. Carlton, " and I hope my boy will by that time have learnt so much of shells as to be able to appreciate their beauties."

Willie was very well pleased, and said that he hoped to complete his own little collection at his next lesson, as he had now only to learn the descriptions of one or two of the univalves."

"That is good news, indeed, Willie; but even then you will have a great deal to learn and practise before you will be able to recognize the foreign species at sight, and understand all their peculiarities of form and colour." The little boy modestly answered, that he would try to take pains; and Leslie continued:

"We remained talking with the man for a considerable time, and papa seemed much 
FOSSILS.

amused at some things he told us; but I noticed particularly that both papa and Mr. Desmond looked very oddly when I bought my bit of cliff, which I thought was something very valuable; indeed, I could not imagine the reason of it then, but now it is all clear enough.

"When we left the fossil man we went to the inn to dinner, intending to have had a walk on the beach afterwards, but I had scarcely got there, and gathered a handful of sea-weed for Ellen, when papa found that if we remained longer we should be too late for the steam-boat. So we walked to the pier and went on board. The rest of the passengers soon collected, and we returned home very pleasantly with both wind and tide in our favour; and now we have the pleasant, happy thought of to-morrow."

"Of to-morrow, Leslie! and what new pleasure is in store for you to-morrow ?" said Mrs. Carlton, " you are not surely going out again?"

“ May I tell, papa?” said Leslie; " perhaps I ought not to have said so much without your permission." 
Mr. Carlton smiled, and said he supposed he must allow him to finish his story, as he had given them to understand that there was some pleasure in prospect. "So tell them quickly, Leslie," he said, "for my little Mary is getting sleepy, and must go to nurse, and I should like her to hear the good news as well as the rest; so kiss papa, Mary, and Leslie shall tell !"

The little girl was sitting on her papa's knee; she threw her arms around his neck, and held up her rosy mouth to be kissed, and then turned eagerly to her brother.

Leslie looked very important when he explained to them, that if the next day should prove fine and sunshiny, they were all going, by water, to a place called Shell Nest; that papa had already hired the boat, and that they were to start in the morning as soon as the tide would permit.

This was indeed joyful news for the children, especially when they found that Mr. Desmond and their dear mama were to be of the party.

Mr. Carlton had taken care to secure a large and convenient boat, in order that comfortable 
accommodation might be prepared, "And Mary shall go as well, if she is a good girl," said Mr. Carlton; "so now we will ring for nurse, to put the poor little sleepy head upon its pillow."

When Mary was gone, Willie asked Mr. Carlton whether the place was named Shell Nest because there were really many shells to be found there.

"I should think so, Willie; you will find the common English shells in great abundance, so I should advise you to take your basket."

"I will indeed, papa; and now may I show you a treasure, that we have just brought home from poor Jem Lester; I think we have all met with something valuable to-day."

"I should like to see it, Willie, but I fear we shall weary Mr. Desmond."

"No, indeed, sir, I should much like to inspect Willie's new acquisition, whatever it may be ; it always give me pleasure to see children rationally amused, and capable of appreciating the beauties of nature. My little friends will, I am sure, thank you in future years, for having led them so early to notice and admire the 
works of the great Creator. I do not think it possible that their young minds can begin too early to trace the hand of Omnipotence, in the minute working and arrangement of even the smallest productions of creative power."

Mr. Carlton.-_"We have to thank Miss Eldon for introducing these pleasant studies to our notice. In my own youth, I was not privileged to have them pointed out to me, and I often felt the want of mental recreation and amusement. I therefore doubly value the advantage for my children-but what have we here, Willie? something alive, surely : indeed, you have found a curiosity!"

"We have indeed, papa; it is a cluster of living specimens of the Lepas Anatifera, or duck barnacle, and Miss Eldon has promised to preserve them for us in spirits, because they lose so much of their colour in being dried.

" They are indeed beautiful," said Mr. Desmond, "I never saw a handsomer specimen; but they ought to be preserved to-night, for if they begin to decay before they are placed in the spirit, they will lose their brilliancy of colour, and become flaccid and poor." 
"You may fetch the glass jar and the bottle of spirits, Willie," said Miss Eldon; "and when you have examined them sufficiently, we will put them in."

Willie did as he was desired, and then looked with wonder at the singular and delicate formation of these curious little creatures. The finely formed tentacula upon the head, which look like a plume of pure white feathers gracefully curled at the extremity, and the many-coloured and beautiful stems, were particularly admired; and Mr. Desmond discovered that there were two distinct species in the group. Miss Eldon had not noticed it before, but now saw with great pleasure that they had really obtained a very rare and curious variety, the eared Cineras. It was smaller than the common kind, and striped with a rich deep purple on the white stem.

Mr. Desmond carefully removed them from the wood, and assisted in tying a piece of coarse thread round the peduncle, and passing it through the cork of the jar, so that when they 
were placed in it, the thread could be drawn up and tightened at pleasure.

This operation occupied some time, and when it was completed it was nearly nine o'clock. So the children wished their papa and mama "Good night," shook hands politely with Mr. Desmond, and with many pleasant anticipations of the coming day, retired with Miss Eldon. 


\section{( 99$)$}

\section{Chapter IX.}

THE DISAPPOINTMENT-INDUSTRY THE BEST CURE.

LESLIE, notwithstanding his fatigue, awoke very early the ensuing morning, and jumping quickly out of bed, ran to the window to look out upon the weather. Alas for poor Leslie! The sea was rolling darkly and heavily, the wind had risen, and the white foam on the distant breakers showed that a storm was at hand; besides this, the sky was overcast, and a light drizzling rain was already falling. He went back to bed very sorrowfully, and awoke Willie, to tell him the sad news. Willie was very sorry, for he had thought with great pleasure of the promised trip; but he persuaded Leslie not to disturb his sisters just at present, as it seemed a pity to wake them so early, merely to tell them of their disappointment.

"Well, Willie, I suppose you are right," said poor Leslie; " but is it not provoking to think 
that this tiresome storm should come on the day of all others when we wanted it fine?"

"You forget, Leslie, that you would have been equally disappointed had it commenced yesterday, and prevented your going to Dover. Indeed, I would rather the weather should prevent our going than almost anything else : suppose, now, either of us had been idle or careless, and obliged to remain at home for a punishment; or that dear mama had been worse and unable to go! Now, we are quite sure that papa will take us on the first suitable day, and we may hope that dear mama will be even better and stronger, and the more able to walk about and enjoy the excursion."

Leslie._- Well, Willie, I don't pretend to be a philosopher; and I don't like to be disappointed when I set my heart upon anything!"

Willie.- "I am sure, Leslie, I do not like disappointments either, but it is of no use to fret about what cannot be mended: and only listen how high the wind is now! I think it is a very happy thing that we are not obliged to be exposed to such weather. But come, we may 
as well get up as we are awake; we shall have time to do something or other before breakfast, and then we shall be ready to comfort poor Ellen and little Mary, when they come down, for you know it is not to be expected that they should bear the disappointment as well as we can do."

But Leslie turned sulkily round, and said, he should not get up at five o'clock, such a disagreeable, dismal day; it would be quite long enough without that, he was sure.

Willie thought otherwise: so he quickly dressed himself; and having knelt down to thank his Heavenly Father for the quiet and refreshing sleep he had enjoyed, he crept softly down stairs, and set himself busily to work with his shells and books. "Indeed," thought Willie, "I shall enjoy my visit to Shell Nest all the better for having finished the class univalve; I shall then have nothing to do but pick up my shells, and see how many of them I am able to arrange and classify without assistance-and dear Miss Eldon will be so pleased!" 
At this moment he heard a gentle step on the stairs; the door opened, and Ellen entered the room. "Oh! Willie," she said, "is not this a dreadful disappointment? The roaring of the wind down the chimney woke me before it was light, and I was so miserable I could not lie in bed; and there you are, I declare, seated as quietly at your books as if nothing had happened: don't you see how it is pouring with rain?"

"I do indeed, Ellen, but it is of no use to fret, so I thought I would try Miss Eldon's plan, and set myself to work: she has often told us that it is the best cure in the world for disappointment; so $\mathbf{I}$ advise you to try it, dear Ellen. Get the basin of water, and you can sort and wash the beautiful weeds that you collected yesterday, and then you will be able to press them directly after breakfast. And now, dear, you must not speak to me for full ten minutes; these names are rather troublesome to remember, but when I know them perfectly we will have a nice pleasant gossip till Miss 
Eldon comes down. We can find plenty to talk about, you know."

So Willie resumed his book, while poor Ellen walked disconsolately to the window, and stood for a long time watching the drops of rain as they pattered in quick succession against the glass: but the longer Ellen thought about it the more she felt convinced that Willie was right; so she tried to banish the ill humour that she felt just ready to rise, and at length began to examine the contents of her basket.

In about a quarter of an hour Willie had finished his lesson, and said that he was quite ready for Miss Eldon whenever she could conveniently hear him; so he took his little stool to Ellen's side and assisted her in sorting her weed.

"Indeed, Ellen," he said, "much as I love my own study, I cannot help thinking that yours is almost as interesting. I think I shall want to learn about the Algæ myself if ever we should visit the sea-side again.

"I often fancy, Ellen, that I shall have more time and opportunity to attend to these interest- 
ing studies than any of you, for you know I am not strong, and even now I am often unable to walk as far as you, without feeling tired and ill; and if I should get worse, it will be very pleasant to stay with dear mama and learn about these beautiful things, when I am not able to go out and look for them myself: and you will bring me home shells and seaweeds, will you not, dear Ellen?"

"To be sure I would, Willie; but I hope that you and dear mama will both be getting stronger every day; and then if we should come down here again, which papa says is very probable, we shall be able to have many pleasant trips together, in search of the beautiful and curious treasures we both like so much."

"Well, dear Ellen, I know I shall be very happy with you and dear mama, and Miss Eldon to amuse and take care of me, but I often think that I shall perhaps give you a great deal of trouble. You know Dr. Percy said before we came down, that if I did not get stronger during this visit, I must be obliged to lie upon the sofa several hours in the day; and 
I cannot help thinking that I am rather weaker than stronger since we came to Ramsgate."

Ellen kissed him affectionately, and told him not to be low spirited, for she hoped he would soon be quite well.

While she was speaking, they heard a loud cry in the nursery, and both ran hastily up stairs to see what was the matter.

It was poor little Mary. Nurse had just waked her, and the little girl had jumped up with great joy to be dressed for the promised excursion; but when she heard that it was a wet morning, and that it would be impossible for her to go in the pretty boat, she gave way to her vexation and burst into a violent fit of crying. Miss Eldon had hastened to the nursery, and sat with the little sobbing girl upon her knee, trying to comfort her. It was in vain for some time, but at length the tears were dried, and she allowed nurse to dress her; but even when Miss Eldon took her hand to lead her down to breakfast, poor Mary's face looked so sorrowful and so sadly inclined to cry, that when Leslie met her on the stairs and laughed at her 
rueful countenance, it instantly brought back her sobs and lamentations.

"What is the matter with my little Mary?" said Mr. Carlton as he joined them on the landing; "surely my little girl is not crying because God has sent the sweet cool rain to water the flowers and make the corn grow? Mary must not be selfish ; she must remember that the rain that disappoints her and keeps her at home to-day will be very gladly watched by those who know how much the earth requires these refreshing showers."

The child kissed her papa and again dried her tears; but Miss Eldon reproved Leslie for his unkindness to a little sister so much younger than himself, and who could not be expected to bear a disappointment so well.

Leslie felt quite ashamed, as well he might when he remembered his own impatience and ill humour.

Mr. Carlton told the children that he hoped they would try to bear this little vexation patiently. He did not think it at all likely that it would be fine for two or three days to come: 
the wind appeared to be rising with the flowing tide, and, as it blew directly from the north-east, there seemed every probability of its continuing for some time; "but," he said, "we will have our promised trip on the first fine and suitable day, and I shall be glad to find that this little trouble does not make my children listless and idle; patience and employment are the best cures in the world for disappointment."

"Just Willie's own words, papa," said.Ellen; "he has been at work for more than an hour this morning already."

"I am very glad to hear it, my dear; depend upon it Willie is right, and I hope you will all follow his wise example. What do you think about it, Leslie?"

"I should like, papa, if you can spare time to attend to me, to read a little Latin with you. Mr. Desmond told me yesterday that it would be wise to refresh my memory as much as possible, that I may not be obliged to go to the lowest form at school."

"Very well then: now we will go to breakfast, and pray let mama see cheerful faces when she comes down stairs." 


\section{$(108)$}

\section{Chapter X.}

THE RECONCILIATION-REMARKS ON THE ALG Class UNIVALVE.

Th $\mathrm{e}$ little countenances were soon looking bright and happy, and after breakfast the children applied themselves diligently to their appointed amusements; even little Mary took her basket of pretty stones, and began a long story to her doll about being good and patient, and learning to amuse herself in-doors when it was too wet to go out.

Leslie, who was sorry for having been unkind to his little sister, remembered that he had found a piece of amber and a glittering morsel of crystal for her, and he was glad to obtain a warm affectionate kiss in token of forgiveness.

Willie and Ellen were both anxious to obtain Miss Eldon's attention; but Willie knew that it would not be polite to let his sister wait until last, so when their kind governess said that she was ready, he begged Ellen to go and take her lesson first. 
Ellen had just risen for the purpose when Mrs. Carlton opened the door, and begged that she might have the pleasure of their company in the drawing-room, as she thought the amusement had been of service to her the day before, and she wished to press a little more sea-weed.

This was very delightful, and as soon as Ellen had placed the dishes, and selected the weed for her mama to begin pressing, she repeated to Miss Eldon a few particulars respecting the sea-weeds, which she had learned on the previous day, and which she wished to be quite certain she understood before she preserved any more. She repeated as follows :-

"The Algæ have their appointed and regular seasons of growth and fructification in the same manner as terrene plants. Some are annual, living but one year; others biennial, and perish at the end of the second season; while some, particularly those having a woody stem, live and grow for several successive years.

"Many of these coarser plants are furnished 
with a tough and fibrous root, so that they are enabled to cling firmly to the weather-andmain-beaten rocks they inhabit.

"Some of the smaller plants take root on the stems of other species, while others grow only on chalk or sand-stone.

"The leaf which forms the principal part of the sea-weed is called a frond; and it is on this that fructification takes place: here the pods grow that contain the seeds or sporules.

"Sea-weed used to be considered a perfectly useless article, but it is now applied to various important purposes. Some of the large, dark plants are burnt to make kelp, and the money and food received in exchange for their ashes form the entire support of many families in the Scottish Islands.

"Some of the smaller weeds are valuable in medicine, or are eaten as salads. And from one kind, the Fucus canaliculatus, butter is made by bruising the weed with lard, and submitting it to various processes of melting, straining, \&c.; this butter is made use of ir Wales, in dressing meat and fish. 
"The Algæ are divided into twelve families, each again subdivided into a number of genera and species; their names are very difficult, and I do not think I am yet able to repeat them all."

Miss Eldon.- "Well, never mind the long names this time, my love; you have remembered the description very well; so now bring your microscope, and I will tell you something about these pretty corallines, of which you are so anxious to learn. But remember that you must not confuse them with the sea-weeds: they belong to quite a separate branch of study; but as they are found together, and often exhibited in the same portfolio, it is right you should know something about them.

"They are distinguished from the sea-weeds by their being composed of a brittle, horny substance, generally of a pale yellow or buff colour; and they preserve best by being allowed to retain the salt particles which adhere to them on being first cast from the sea. There are many very beautiful varieties, but I shall not confuse you by mentioning their names. 
They are called zoophytes, and are supposed to partake the nature of both animal and vegetable substances.

" They, like the coral, form the habitation of a living Polype: and could you see these curious little creatures by the aid of a powerful microscope, as I have done, you would be indeed astonished; they appear to be full of life, and throw out a number of tentacula, which, like the horns of a snail, shrink from the touch, and appear to serve the purpose of feelers in searching for food, and warning them of the approach of an enemy.

"These little animals, on examination, present various beautiful shapes and colours. Some of them look like bunches of minute roses or stars; all, however, in motion, and varying every instant.

"A coralline containing a living Polype is not often found; except, perhaps, thrown from deep water after a storm, or occasionally dragged from the rocks by the dredges of the oyster fishers. Those that we usually find on the shore are quite empty, and consequently 
have lost the rich colours they exhibit while inhabited by the living Polypes.

"You have a nice piece of sponge here, and you will, I think, be surprised to hear that this also has animal life, and is supposed to obtain all its nutriment by absorbing and rejecting sea-water.

"The large sponges in common use are chiefly brought from the Mediterranean Sea, and are procured with great difficulty. The poor men who gather them are exposed to much hardship, and are often obliged to dive several fathoms to drag them from the rocks they inhabit. But bring your glass, Ellen. I should like you to examine this very minute coralline, which grows, like many of its species, on the surface of a sea-weed. Do you see how exactly and delicately the little cells are formed? You might fancy you were looking at a piece of miniature honey-comb. Do you not think it very beautiful?"

"I do indeed, ma'am," said Ellen, " and am much surprised at what you have told me. I find something new and wonderful every day." 
"You need never live a day without doing so, my dear Ellen; you have only to keep looking out for these beauties and wonders, and you will be sure to find them. The stores of nature are inexhaustible; and the more you see of them, the more ready you will be, I trust, to admire and praise the bounteous hand that has created all these curious and beautiful things." Ellen took the glass and coralline to her mama, and afterwards to Willie and Mary, that they might have the pleasure of examining it too; and, after thanking Miss Eldon for her kind instruction, she resumed her seat.

It was now Willie's turn. The little boy came with the univalve shells in his basket, ready to arrange in the box, as he repeated their names to Miss Eldon. He thus began:

"A univalve shell is known, as the word signifies, by its being composed of only one valve or piece; and the genera are chiefly distinguished from each other by the shape and position of the mouth.

"The first of the class is the Conus, or cone. It is easily known by its conical form, 
and by the long narrow mouth and polished surface. The colours are bright, and often curiously marked. The cone is found chiefly in hot climates.

"The Cypræa, or cowry, is another polished shell; at least the foreign species are very smooth and shining. I have found some small rough ones on the coast here. In India I have read that they are passed currently by the natives as money.

"The Bulla, or dipper; a very thin, transparent shell, sometimes of a pure and delicate white.

"The Volute, or wreath. I have not a common Volute, Miss Eldon, only the one you were so kind as to purchase for me, and I think it seems a very curious shell; it looks to me to be marked with lines and dots, very much like the music that Ellen uses at the piano."

"It is so, my dear, and for this reason is called the Voluta musica, and very curious it is."

Willie._" The Buccinum, or whelk; the Strombus, or claw shell; the Murex, or rock- 
so called, I should think, from the roughness of many of the species. It is supposed that the beautiful Tyrian dye was chiefly extracted from the mollusk inhabiting this shell, so that in former times it must have formed a valuable article of trade.

"The Trochus, the Turbo, and the Helix, come next; and I have not forgotten the wonderful snail shell. Then the Nerita, or hoof shell; and of this species is the beautiful bleeding tooth, which looks so exactly as poor Mary's gum did the other day, when papa took out her little tooth.

"The Haliotis, or ear shell, is also very beautiful; and poor Jem Lester told me that it is sometimes called Venus's Ear: I suppose because it is so very handsome, and Venus is the goddess of beauty. The Patella, or limpet; the Dentalium, or tooth shell; the Serpula, or creeper, which contains some beautiful varieties; then the Teredo, or ship worm, which I have not been able to find."

Miss Eldon._-" Never mind, Willie, I have been more fortunate; but I thought I would 
wait until you came to the shell before I gave you the specimen. I am sorry to say that it is not quite perfect; but I have a mollusk preserved in spirits for you, and you must be contented with this broken shell: they are seldom found quite entire. It is imbedded, you see, in a piece of decayed wood, probably the fragment of a wreck."

Willie was much surprised to see that the shell passed through the centre of the wood, and he wondered very much how it had been possible for the animal to place it there without materially injuring its delicate structure. He listened with astonishment when Miss Eldon explained to him that the mollusk is supposed to be furnished with a secretion of some kind, which is capable of dissolving the wood.

"They are," she said, " exceedingly destructive to shipping; they pierce and destroy the hardest timber. It is very remarkable, that in whatever number they are found in the wood, they are never known to cross or intersect each other, but appear capable of turning 
or winding their shells at pleasure. Notwithstanding the mischief they often produce, they are still useful in some respects. They destroy the large trees, which in distant lands are uprooted by hurricanes or earthquakes, and would else choke up the rivers into which they fall, or render it dangerous to navigate the seas into which those rivers discharge themselves. Now go on, Willie."

Willie.- "The Sabella, which seems to be formed with particles of sand or broken shells, which are more or less closely connected by some glutinous substance. This is the last shell I have, but I think I can describe the Nautilus and Argonauta, the only two of which I have not a specimen."

Mrs. Carlton.- “ Do so, my dear boy, and I will cheerfully give you the shells when I can meet with them, as a reward for your care and diligence."

Willie.—“ Thank you, thank you, mama. I know where to get them both, but they were expensive; and Miss Eldon thought, that as 
my own money is nearly gone, it would be better to consult you about purchasing them.

"The Nautilus, or sailor, is a smooth and beautiful shell, containing many chambers separated by plates of pearl, and united by a tube which, by enabling the animal to take in air or water at pleasure, assists it in rising or sinking in the water. These shells vary much in size; and the largest of them are sometimes made into drinking cups, flower vases, \&c., and are capable of receiving a high polish.

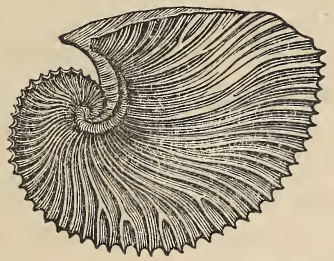

"The Argonauta, or paper Nautilus, has a thin transparent shell, and is even more elegant in form than the common species. In shape it resembles an ancient boat, and appears to be united by a keel. The curious little animal that inhabits it is furnished with a membrane answering the purpose of a sail, which it can 
unfurl, or withdraw in an instant at the approach of danger, when, the water being received into the shell, the Argonauta sinks by its own weight.*

"And now, mama, may I repeat to you a short poem about the Nautilus. I met with it the other day in my little green book, and it seems to me to describe it well."

Willie obtained permission, and repeated as follows:-

$$
\text { “THE NAUTILUS. }
$$

"Two feet they upward raise, and steady keep; These are the masts and rigging of the ship. A membrane stretched between supplies the sail, Bends from the masts, and swells before the gale. The other feet hang paddling from the side, And serve for oars to row, and helm to guide. 'Tis thus they sail, pleased with the wanton game, The fish, the sailor, and the ship the same. But when the swimmers dread some danger near, The sportive pleasure yields to stronger fear; No more they wanton drive before the blasts, But strike the sails and bring down all the masts, The rolling waves their sinking shells o'erflow, And dash them down again to sands below."

* This membrane is affixed to two of the tentacula, while the others serve the purpose of oars, and hang over the sides of the shell to propel and guide the little bark. 
Mrs.Carlton.- "Very appropriate and pretty indeed, my dear! And now I suppose your collection will be complete."

Willie._-"Yes, dear mama, it will indeed. I shall have a specimen of all the Linnæan classes; but Miss Eldon says, that when I am old enough to have a cabinet, and arrange them according to the smaller divisions of Lamarck and other naturalists, I shall constantly meet with something new, and be able to add to my collection every day; so that now I am only learning, as it were, an introduction to the science of conchology. I hope I shall some day understand it more thoroughly. But you know, dear mama, we have only two weeks more to spend at Ramsgate, and when we get back to London these studies are only to serve as recreation; we must then attend diligently to history and geography again."

Mrs. Carlton.-_"Very true, my love; and now do you know it is almost dinner-time, and here are papa and Leslie come to see what we are doing."

The children were all surprised to find that 
the morning they had looked at so sadly had passed pleasantly and quickly away. The rain and wind seemed to increase rapidly, but every little face was dressed in smiles, and every heart was happy and tranquil as if no disappointment had happened.

"See my children," said Mr. Carlton, as he looked kindly at them, "what a delightful thing it is to be well and usefully employed! how much better than standing at the window with sorrowful faces to complain of that which you cannot remedy!" 


\section{$(123)$}

\section{Chapter XI.}

IN-DOORS AMUSEMENTS - THE VISIT TO SHELL NESTTHE COAST.GUARD'S HOME-THE FALL-THE SUDDEN RETURN.

The two succeeding days were equally wet and stormy, but the children did not complain any more; they seemed willing and ready to wait until the swell of the sea might abate, and render it pleasant and smooth for sailing. They amused themselves sometimes with their books and shells, - at others, standing at the window to watch the flight of the sea-gulls, as they skimmed the surface of the angry billows; or to look with anxiety at the struggling vessels, as, with lowered masts and half-reefed sails, they attempted to make the harbour. Once they saw a small bark in such excessive danger, that the poor sailors had mounted the rigging, thinking it impossible that the vessel could reach the port in safety; and heartily did the children rejoice when, after tacking in this 
peril for a considerable time, a sudden lull of the wind enabled them to try with more success, and they at length anchored safely in the outer basin.

Mr. Desmond, too, was now a frequent visitor, and he had always something new and interesting to tell them; but, more than all, their dear mama seemed to be gaining strength daily, and she was now able to sit with them frequently, and to walk about the house without difficulty.

When the rain had ceased, and the wind had a little subsided, Mr. Carlton took them for a walk on the cliff, that they might see the number of vessels in the harbour, with their white sails spread to dry in the sun and wind; but it was not until more than a week had elapsed that he thought it would be wise to attempt the promised excursion. But the day came at length, and our little friends joyfully hailed a fine pleasant morning, a calm sea, and the joyful announcement that all was ready.

Mrs. Carlton rode down to the pier, that she might not be fatigued before starting. Miss 
Eldon and the children walked at her side; and when they reached the boat they were delighted to find their papa and Mr. Desmond already seated in the stern.

The cushions were soon arranged for Mrs. Carlton, the hamper of provisions safely placed in the boat, and away glided the little vessel with its happy passengers. When they had rowed into the middle of the basin, the sail was hoisted, and they bounded away through the sparkling waves, without one regret that they had been so long waiting for the pleasure they now enjoyed.

They laughed and sang merrily as they sailed along, and the children put their hands over the side of the boat, to catch the small pieces of sea-weed as they floated past them; then the fresh cool air made them hungry, and they were glad to find a large bag of biscuits to amuse and refresh them. At length Leslie exclaimed :-

"Oh look, papa! look at that great black fish! did you see it rolling along in the water? See, there it is again, and yonder's another!and another!" 
"They be porpoises, young gentlemen," said one of the sailors; "there have been great shoals of them passing this last week. 'Tis the stormy weather, sir, that brings them; but we shan't see them much longer, for I think it has settled fair again."

The children were much amused to see the great clumsy animal rolling over and over; sometimes leaping heavily out of the water, and evidently enjoying the warm sunshine.

Mr. Desmond told them that the porpoise is sometimes called a sea-hog, from its clumsy and singular shape, and the grunting, blowing noise it often makes.

The sailor said that in calm weather he had heard them snore at a great distance from the boat; and that they then appeared to be sleeping. He also told them that their skin is so thick that common shot have not the slightest effect upon them, but bound from their sides like marbles; though many gentlemen amuse themselves in the summer time by shooting at them.

"Rather a cruel amusement, I think," said 
Mrs. Carlton, "considering that the animal is not of value, even should they succeed in killing it."

"I've thought so, myself, ma'am," answered the man; "for my own part I'd a'most as soon shoot at a Christian; the poor thing seems so sensible and harmless.*"

They saw many other amusing things as they passed along; and they were all surprised to find themselves so soon at their destination. They landed on a flat, sandy-looking shore, which did not appear to contain any thing remarkable; but Willie soon discovered that there were shells in great abundance lying about; and he immediately began to collect the best and prettiest he could find to fill his basket. The sun at this time was very hot; and as there did not appear to be any other shelter near, the boatmen fixed their oars in the sand, spread the sails over them, and thus made a pleasant awning under which to pro-

* The sailors in this vicinity look upon the porpoise with a kind of superstitious veneration. It is a common exclamation among them, "I'd a'most as soon harm a Christian." 
pare dinner. And a very pleasant dinner it proved to be.

Mrs. Carlton was supplied with plenty of pillows, but there were neither chairs nor tables to be had, so the rest of the party were obliged to sit in a circle on the ground, while the plates and dishes were ranged in the centre; but these little inconveniences seemed only to enhance their pleasure. Many and many a cheerful, ringing laugh went round, and all agreed that chairs and tables had never accommodated a merrier party, or sustained a more delicious dinner.

When this was over, the children spent another hour in looking for shells, and in trying experiments upon a small tract of quicksand, which Leslie had discovered, and which was so soft and boggy that it could not sustain even little Mary's weight, who sank in nearly up to her knees, as she ran swiftly along the shore to show Willie a new treasure she had just discovered on the sand.

It was now proposed that they should take. a walk in quest of the coast-guard's house, 
which the sailors told them might be found at a very little distance along the coast. They soon came within sight of a low, dark building, which Willie supposed to be only the hull of a wrecked vessel cast on shore by the waves; and he was much surprised when his papa told him that this was the guard's cottage. "But you were right in supposing it to be the hull of a vessel, my dear. Many small barks that are unfit for sea are thus used on the coast; and you will see that they make very warm and comfortable habitations for the poor men who inhabit them, and who are so often exposed to the violence of the wind and weather: but we will go up the ladder and hear what the good man says. So off with you, my boys! you see mama is already at the top."

And doubtless they would have very much enjoyed examining the curious little dwellingplace, which appeared so new and extraordinary to them; but at this moment an accident occurred which diverted their thoughts from every other consideration, and gave them all much pain and uneasiness. 
The ladies had safely reached the deck of the vessel, and Leslie and Willie were half way up the side, when the latter accidentally missed his footing, and fell with great violence to the ground. Mr. Carlton raised him in much alarm; but although the child looked pale and frightened, he said he was not greatly hurt, and that he should soon be better if he had a little rest. So Mr. Carlton assisted him up the side of the ship, and the coast-guard's wife kindly brought a draught of milk to refresh him. The poor boy tried to look cheerful, and assured his mama that he felt very little pain, and begged that she would not be anxious about him.

Had this misfortune happened to a strong healthy child, it would have been passed by with comparatively slight notice; but Dr. Percy had frequently said, that a fall or sudden jar might prove of serious consequence to Willie, who was, as we have said, extremely delicate; and had of course been guarded with the greatest care and attention. Willie felt glad that he had not been running or jumping 
carelessly, for he would have been sorry that his own thoughtlessness should have occasioned so much regret and alarm to his kind and watchful friends; but he knew that his fall had been the result of accident, and he felt that self-will on his part would be both ungrateful and foolish; and although he felt sorry to give additional trouble, he immediately acquiesced in his papa's wish that he should not attempt to walk again. So with Mr. Desmond's kind assistance he was carried to the boat, as soon as Mrs. Carlton felt sufficiently rested to resume her walk; and they left with many expressions of gratitude to the worthy coast-guard and his wife, who had offered them so much kind attention. They found that the boatmen were looking out for them, as the tide was favourable to their setting out on their return immediately.

The sail home was a very silent one; all their mirth and merriment had ceased. Willie leaned his head on his papa's shoulder, and looked pale and weary; but all hoped that a night's rest would be of service to him; and 
trusted that the fall would not produce any very serious consequence.

When they landed, the chair was waiting for Mrs. Carlton; and one of the sailors kindly offered to carry the young gentleman home. As soon as they arrived, the little boy, who now complained of pain in the head and back, was put quietly to bed, and soon fell into a tranquil sleep; but Mrs. Carlton passed a night of much anxiety, and was watching at his bedside at a very early hour the next morning. She was concerned to find that, although still asleep, Willie's cheek was flushed, and his breathing heavy and irregular; and she thought that it would be right to place him as early as possible under the care of a medical attendant. Their kind friend Dr. Percy had attended him in several previous illnesses, and she felt that she could not confide him to any other with equal confidence.

It was now only four o'clock; and when she mentioned the subject to Mr. Carlton, he proposed that Miss Eldon should be asked to take charge of the little sufferer; and that he should 
himself accompany them to London that very morning, and return at the end of the next week to fetch Mrs. Carlton and the rest of the children. This was at first agreed upon, but Mrs. Carlton felt extremely anxious to hear Dr. Percy's opinion at once. And she said, that if it were not for disappointing the children, and depriving them of the additional week, she should much prefer that they should all go together at once.

"If that is the case, my love," replied Mr. Carlton, "we have no time to lose. Nurse can accompany us to take care of Lucy, and cook must remain for a day to bring the remainder of the luggage. I will go and call them immediately; and I am sure our dear children love their brother and their mama quite well enough to acquiesce without a murmur."

Mr. Carlton was quite right: the lesson of the previous week had not been lost upon them; and when they found that this new anxiety was likely seriously to affect their dear mama's scarcely renewed health, and that poor Willie, always so patient and affectionate, was really 
suffering, they seemed to vie with each other in showing their sympathy and kindness, and frequently assured him, that they considered one more week at the sea-side of little value in comparison with their mama's comfort and his speedy relief and restoration.

So the pleasant visit abruptly and unexpectedly terminated; a few necessary articles were hastily packed; and at nine o'clock the whole party were on their way to London. 


\title{
Chapter XII.
}

\author{
CONCLUSION.
}

* $\quad * \quad * \quad * \quad * \quad *$

Our young friends must imagine four years to have elapsed since the accident occurred which we have described to them in the foregoing Chapter.

Willie's fall had confirmed a spinal complaint which Dr. Percy had long feared would be likely to attack him; and nearly the whole of this long weary time the patient boy had been confined to his sofa, obliged to lie constantly upon his back, and to give up walking altogether. He had occasionally suffered a great deal of pain, but this was not always the case; he usually looked contented and happy, and rarely gave way to anything like fretfulness or complaining.

But on the morning that we again introduce him to the reader, there were traces of tears on 
his pale cheek; and, although he held a book in his hand and was trying to read, he seemed quite unable to rivet his attention.

Mary too was sobbing at the window; and even Mrs. Carlton, who was working at the table, appeared to participate in their grief, and remained silent and sad. At length Willie spoke:

"It's of no use fretting, Mary," he said; "we have all parted with a kind and dear friend; but we know what her advice would be, could she see us at this moment: she would tell us to put away our tears and find something to occupy our minds."

“Dear, dear Miss Eldon!" sobbed poor Mary; "I cannot bear to think that she will never come back to us again. I am sure we shall not find any one else so kind and good as she has been!"

"But she will come back to see us, Mary; you know she promised that she would-and crying is not of any use,-is it, dear mama?"

"No, my poor boy, it is not indeed; and if you can try to conquer your sorrow, who will 
feel her loss more than any of us, I am sure Mary will endeavour to restrain her tears too, if it is only for your sake."

"I will try, mama,-indeed I will! but even Miss Eldon;-I cannot say Mrs. Desmond yet, mama,-even Miss Eldon cried when she bade us good bye, although she had looked so very happy before; and I dare say Ellen is crying too, only she is gone up stairs that we may not find it out."

"Very probably, my dear, and I should think it strange if we could any of us part with so kind a friend without pain. I expect even poor Leslie will look somewhat grave when he returns from school, and misses his kind and patient governess, who so often bore with his faults and assisted in promoting his pleasures."

"I know he will, mama," said Mary; "and one seems to feel it more at Ramsgate than any where else; for it was here that she told us of so many pleasant things, and first taught us to love the beautiful works of nature."

"Well then," said Willie, "I will tell you what we will do, Mary; you shall fetch her 
parting present to me, the box of minerals, and I will give you your first lesson about the 'pretty stones,' as you used to call them, when you were a little girl at the time we first visited Ramsgate. How do you like my plan, love?"

"Oh very much indeed," said Mary, drying her tears; "I am sure it is a good one, and we will all try to act just as dear Miss Eldon would approve of, if she were with us now."

So she brought down the box, and, placing her chair by Willie's sofa, began her lesson. But she first coaxingly told him that he must not give her anything very difficult to learn to-day, as she feared she should not be able to remember it so well as usual.

"No, dear, you shall not learn anything by heart now; only listen attentively and I will tell you the meaning of the word mineralogy, and the names of some of the most common specimens. When you were a little girl, Mary, you used to be very proud to think you should be called a mineralogist.

"Well, the word mineral signifies all the 
substances of which the body of the earth is composed, except those which are supposed to be the remains of organic life. These are called fossils, and are studied chiefly by geologists, who, as you know papa told us the other night, comprise in their examination the entire crust of the earth, and try to discover the means by which the rocks and earths have been placed in particular directions, and at certain distances from each other. Theirs, you see, is a very extensive branch of pursuit; ours is more within compass; for it is possible, as you perceive, to have a very complete collection of minerals contained within a little rose-wood box. It is rather difficult to classify them, as they cannot always be distinguished at sight in the same manner as shells or fossils. They are known by various signs and characteristics,-such as hardness, transparency, frangibility, or the degree of difficulty with which they are broken, and sometimes even by taste and smell: but the chief distinction is the materials of which they are composed; and in order to understand these thoroughly, some little knowledge of chemistry 
is requisite. So you see, dear Mary, you will be obliged to pay some attention to all these matters before you are able to tell at once the name and classification of a mineral."

"Well, dear Willie, I shall not mind a little trouble to acquire this useful knowledge; and it will be so delightful to bring you home new specimens, now that you are unable to look for them yourself,-and dear sister Ellen is my governess now, you know. I am sure she will like to see me study mineralogy."

"To be sure she will, Mary! it was at Ramsgate we first learnt to like these pleasant studies, and here we obtained our first specimens, and here too you know we first saw Mr. Desmond, who has been so kind and given us so much assistance. Who would have guessed when he came to tea with us that merry, happy evening, that he would take away our own dear Miss Eldon? Do you remember that evening, Mary? I should scarcely think you can!"

"Oh! yes, indeed, Willie, I remember it quite well. The next morning, you know, brought 
our great disappointment; and I have often wished since that we had not gone to Shell Nest at all.”

"Never mind that, dear, I am very happy, although I cannot run about as you do, and I might have fallen at home, and you know Dr. Percy gives me great hope now; but we are forgetting our lesson, and see! mama is putting away her work."

Mrs. Carlton._- " I shall leave you now, my dears; I see that employment has done you both good, and I must go and look for poor Ellen and Lucy, and advise them to follow the same wise plan. When you have finished, Mary, I will comé to Willie, while you shall all take a little walk on the sands;--but, perhaps, my dear, you will like to be drawn out too?"

"Not this morning, dear mama; I will go after tea, if you please, when it gets more cool and pleasant."

Mrs. Carlton went up-stairs, and Willie resumed: " Now, Mary, some are called earthy minerals, which are all composed of one of nine earths : silex, alumine, zircon, glucine, yttria, 
barytes, strontian, lime, or magnesia. These are all naturally white; therefore if they are coloured in any way, it is because they are mixed with metallic substances.

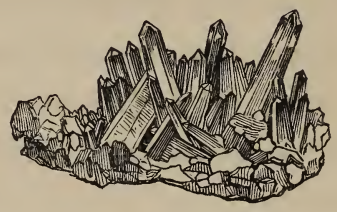

"Now, look at the first specimen in my box. It is called quartz, or rock crystal. See, how beautifully the little pyramids are shaped! they are sometimes known by the name of Cornish diamonds. Here are three more pretty specimens - chalcedony, jasper, and garnet: see how the garnet glitters in the sun! Then comes the agate,-just such a one, only smaller, as that Uncle William had set in gold to make a brooch for mama. This is asbestos, which, although so hard in the mass, is easily divided lengthways by its little silken fibres, which may be separated by the finger and thumb. The topaz and emerald are also earthy minerals. There are many more, but I am only going to give you a sketch this morning. 
"The alkaline earthy minerals are those which contain alkalies as well as earths.-Mica, lapis lazuli, pitch-stone, and pumice, belong to this division.

"Those which contain acids are called acidiferous earthy minerals; some of them are very beautiful, particularly carbonate of lime and fluor spar. The beautiful ornament on Aunt Gerard's drawing-room mantelpiece is made of fluor spar.

"The metallic ores are native gold, native silver, native copper, native iron, lead, and zinc; these all comprise beautiful varieties.

"Last of all are the combustible minerals, including those that have sulphur or carbon for their base.-Sulphur, the diamond, plumbago, and amber, are contained in this division. You have a piece of amber of your own, Mary; do you not remember that you used to rub it on the sleeve of my coat to make it electrical, and capable of attracting the little pieces of torn writing-paper?"

"Yes, I remember it, Willie; and did you not tell me that there was once a curious belief 
that amber was formed by the tears of the seabirds?"'

"Yes, dear; but I think it must have arisen first in the poet's fancy. I remember hearing a little song once, in which these words occur:

-Around thee shall glisten the loveliest amber That ever the sorrowing sea-bird has wept.'"

“Well, it was a very droll fancy," said Mary, laughing; "but, Willie, are you really shutting the box?"

"Yes, dear; go for your walk now : I am so glad to see you smiling again. We have many pleasant things to thank and love our dear Miss Eldon for; but none, I think, have afforded us more delight and amusement than our SEA-SIDE PLEASURES."

London: Printed by C. Roworth and Sons, Bell Yard, Temple Bar. 


\section{ERRA'A.}

Page 15, line !3, for " grasses," read "ferns." Page 36, line 2, for "Mary," read "Nancy." 



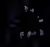

